NUREG/CR-3093

PNL-4566

RZ

\title{
Aerosols Generated by Releases of Pressurized Powders and Solutions in Static Air
}

NUREG/CR--3093

DE83 016859

Manuscript Completed: May 1983

Date Published: August 1983

Prepared by

S. L. Sutter

Pacific Northwest Laboratory

Richland, WA 99352

\section{Prepared for}

Division of Risk Analysis

Office of Nuclear Regulatory Research

U.S. Nuclear Regulatory Commission

Washington, D.C. 20555

NRC FIN B2287 


\section{DISCLAIMER}

This report was prepared as an account of work sponsored by an agency of the United States Government. Neither the United States Government nor any agency Thereof, nor any of their employees, makes any warranty, express or implied, or assumes any legal liability or responsibility for the accuracy, completeness, or usefulness of any information, apparatus, product, or process disclosed, or represents that its use would not infringe privately owned rights. Reference herein to any specific commercial product, process, or service by trade name, trademark, manufacturer, or otherwise does not necessarily constitute or imply its endorsement, recommendation, or favoring by the United States Government or any agency thereof. The views and opinions of authors expressed herein do not necessarily state or reflect those of the United States Government or any agency thereof. 


\section{DISCLAIMER}

Portions of this document may be illegible in electronic image products. Images are produced from the best available original document. 


\section{NOTICE}

This report was prepared as an account of work sponsored by an agency of the United States Government. Neither the United States Government nor any agency thereof, or any of their employees, makes any warranty, expressed or implied, or assumes any legal liability of re. sponsibility for any third party's use, or the results of such use, of any information, apparatus, product or process disclosed in this report, or represents that its use by such third party would not infringe privately owned rights.

\section{Availability of Reference Materials Cited in NRC Publications}

Most documents cited in NRC publications will be available from one of the following sources:

1. The NRC Public Document Room, 1717 H Street, N.W. Washington, DC 20555

2. The NRC/GPO Sales Program, U.S. Nuclear Regulatory Commission, Washington, DC 20555

3. The National Technical Information Service, Springfield,..VA 22161

Although the listing that follows represents the majority of documents cited in NRC publications, it is not intended to be exhaustive.

Referenced documents available for inspection and copying for a fee from the NRC'Public Document Room include NRC correspondence and ir.ternal NRC memoranda; NRC Office of Inspection and Enforcement bulletins, circulars, information notices, inspection and investigation notices; Licensee Event Reports; vendor reports and correspondence; Commission papers; and applicant and licensee documents and correspondence.

The following documents in the NUREG series are available for purchase from the NRC/GPO Sales Program: formal NRC staff and contractor reports, NRC.sponsored conference proceedings, and NRC booklets and brochures. Also available are Regulatory Guides, NRC regulations in the Code of Federal Regulations, and Nuclear Regulatory Commission /ssuances.

Documents available from the National Technical Information Service include NUREG series reports and technical reports prepared by other federal agencies and reports prepared by the Atomic Energy Commission, forerunner agency to the Nuclear Regulatory Commission.

Documents available from public and special technical libraries include all open literature items, such as books, journal and periodical articles, and transactions. Federal Register notices, federal and state legislation, and congressional reports can usually be obtained from these libraries.

Documents such as theses, dissertations, foreign reports and translations, and non-NRC conference proceedings are available for purchase from the organization sponsoring the publication cited.

Single copies of NRC draft reports are available free upon written request to the Division of Tech. nical Information and Document Control, U.S. Nuclear Regulatory Commission, Washington, DC 20555.

Copies of industry codes and standards used in a substantive manner in the NRC regulatory process are maintained at the NRC Library. 7920 Norfolk Avenue, Bethesda. Maryland, and are available there for reference use by the public. Codes and standards are usually copyrighted and may be purchased from the originating organization or, if they are American National Standards, from the American National Standards Institute. 1430 Broadway. New York, NY 10018. 


\section{ABSTRACT}

Safety assessments and environmental impact statements for nuclear-fuelcycle facilities require an estimate of potential airborne releases caused by accidents. Aerosols generated by accidents are being investigated by Pacific Northwest Laboratory to develop the source terms for these releases. An upper boundary accidental release event would be a pressurized release of powder or liquid in static air. Experiments were run using various source sizes and pressures and measuring the mass airborne and the particle size distribution of aerosols produced by these pressurized releases. Two powder and two liquid sources were used: $\mathrm{TiO}_{2}$ and depleted uranium dioxide (DUO); and aqueous uranine (sodium fluorescein) and uranyl nitrate solutions. Results of the experiments showed that pressurization level and source size were significant variables for the airborne powder releases. For this experimental configuration, the liquid releases were a function of pressure, but volume did not appear to be a significant variable.

During the experiments $100 \mathrm{~g}^{\mathrm{g}}$ and $350 \mathrm{~g}_{3}$ of DUO ( $1 \mu \mathrm{m} \mathrm{dia}$ ) and $\mathrm{TiO}_{2}$ ( $1.7 \mu \mathrm{m} \mathrm{dia)} \mathrm{powders} \mathrm{and} 100 \mathrm{~cm}^{3}$ and $350 \mathrm{~cm}^{3}$ of uranine and uranyl nitrate solutions were released at pressures ranging from 50 to 500 psig. The average of the largest fractions of powder airborne was about $24 \%$. The maximum amount of liquid source airborne was significantly less, about $0.15 \%$.

The median aerodynamic equivalent diameters (AED) for collected airborne powders ranged from 5 to $19 \mu \mathrm{m}$; liquids ranged from 2 to $29 \mu \mathrm{m}$. A1 1 of the releases produced a significant fraction of respirable particles of $10 \mu \mathrm{m}$ and less. 


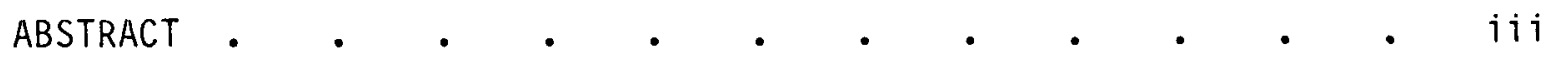

SUMMARY AND CONCLUSIUNS

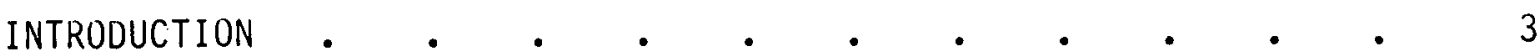

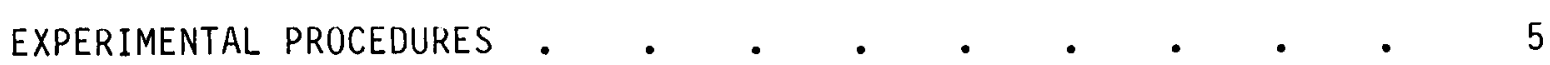

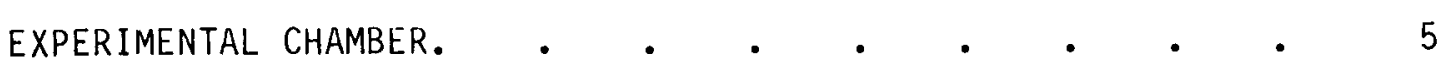

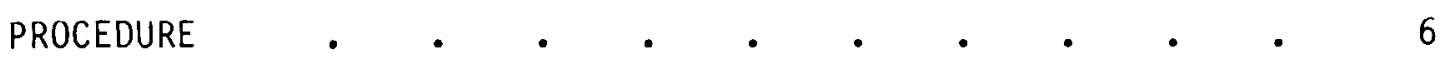

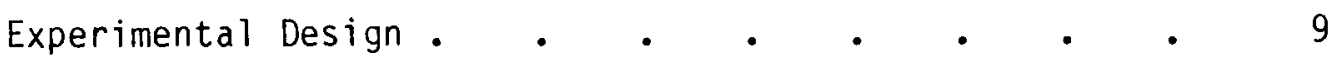

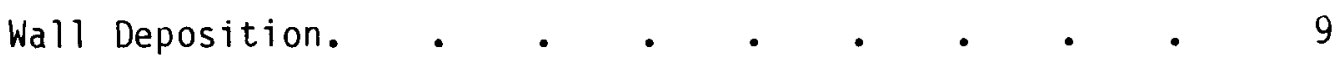

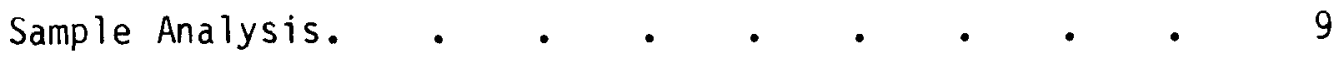

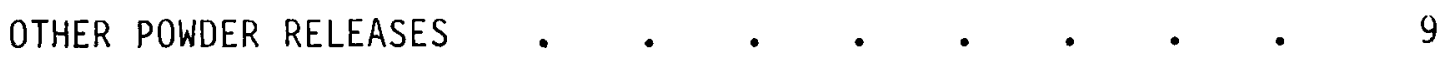

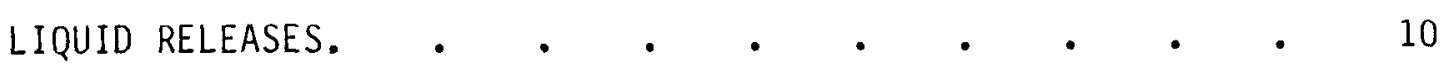

RESULTS AND DISCUSSION

POWDER RELEASES--PARE EXPERIMENTS • • • • • • • • 12

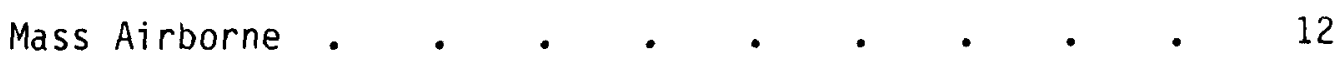

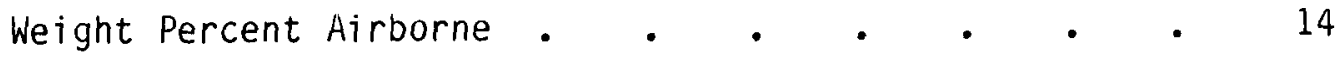

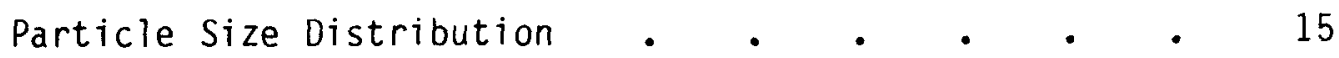

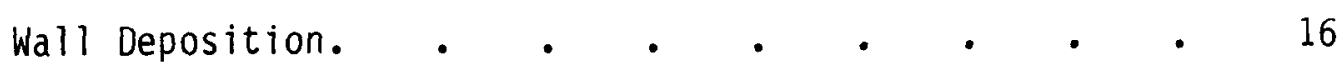

Powder Ejected • • • • • • • • • • 16

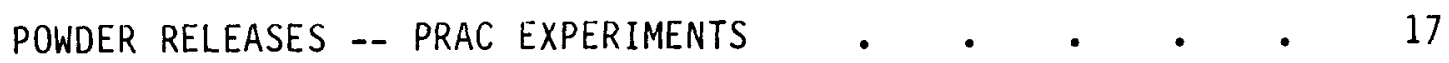

POWDER RELEASES -- OUTOOOR TESTS • • • • • • • 17

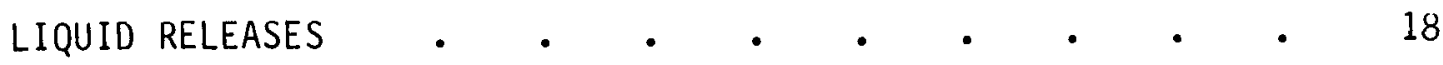

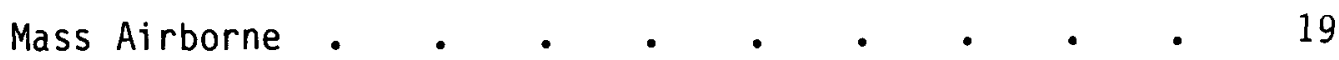

Weight Percent Airborne $\quad$. $\quad$ • . . . 19

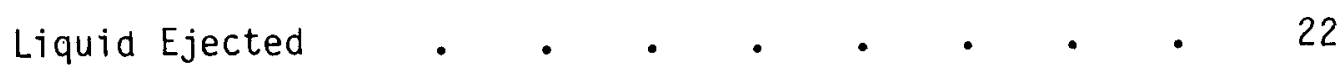




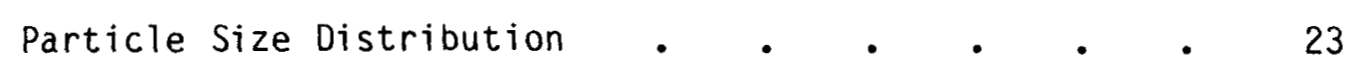

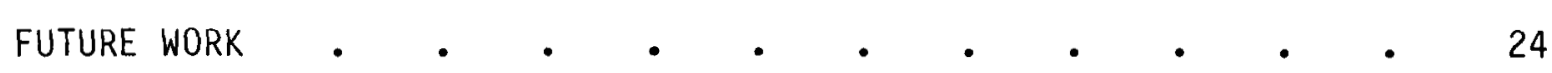

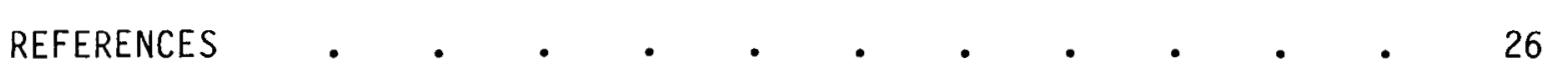

APPENDIX A - MASS AIRBORNE RESULTING FROM PRESSURIZED

POWDER AND LIQUID RELEASES IN STATIC AIR • • • A.1

APPENDIX B - MEDIAN AERODYNAMIC EQUIVALENT DIAMETER (AED) OF PARTICLES GENERATED BY PRESSURIZED

POWDER AND LIQUID RELEASES IN STATIC AIR • • • • B. 1 


\section{FIGURES}

1 PARE, Pressurized Airborne Release Equipment . . . 6

2 Sampling for a Pressurized Release with High $\quad$ Volume Samplers

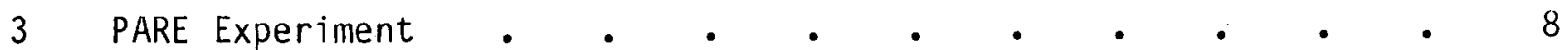

4 PARE Modification for Powder Release Above Chamber

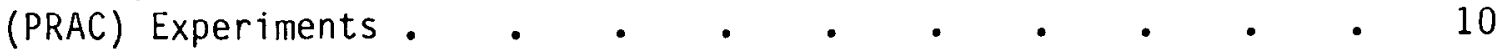

5 PARE Modification for Pressurized Liquid Release

Experiments • $•$ •

6 Mass Airborne from the Pressurized Release of

Two Powders . . . . . • • • • • • 13

7 Average Weight Percent of Powder Airborne as a Function of Pressure . . . . . . . • • . . 15

8 Mass Airborne from PRAC Experiments . • . • . . 17

9 Mass Airborne from the Pressurized Release

\begin{tabular}{l} 
Average Weight Percent of Liquid Airborne as a Function \\
of Pressure . \\
\hline
\end{tabular} 


\section{TABLES}

1 Average Mass Airborne from Pressurized Powder Releases . . 12

2 Average Weight Percent Airborne from Pressurized Powder Release

3 Average Median AED of Particles Size Generated by Pressurized Powder Releases, um .

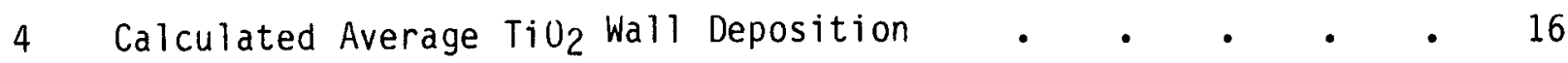

5 Comparison of PARE and PRAC Releases . . . . . . . . 18

6 Results of Unrestricted PARE Pressurized Powder Releases • • 18

7 Average Mass Airborne from Pressurized Liquid Releases • • 19

8 Average Weight Percent Airborne from Pressurized

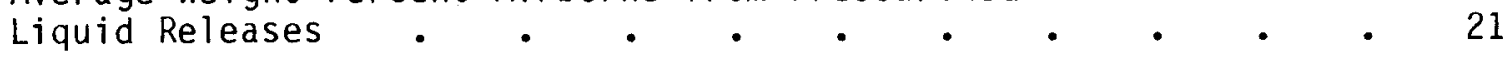

9 Comparison of Weight Percent of Source Mass Airborne from

10 Average Amount of Liquid Ejected from PARE • • • • • 22

\begin{tabular}{l} 
Average Weight Percent of Liquid Released that Became \\
Aerosolized \\
\hline
\end{tabular}

\begin{tabular}{l} 
Average Median AED of Particles Generated by Pressurized \\
Liquid Releases, $\mu \mathrm{m}$ \\
\hline
\end{tabular}

A. 1 Mass Airborne from Pressurized Releases of DuO Powder • • • A.1

A.2 Mass Airborne from Pressurized Releases of $\mathrm{TiO}_{2}$ Powder • • A.2

A.3 $\mathrm{TiO}_{2}$ Powder Airborne, Powder Release Above Chamber (PRAC) • • A.3

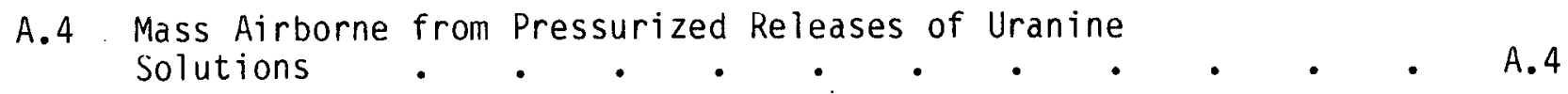

\begin{tabular}{l} 
A.5 Mass Airborne from Pressurized Releases of UNH \\
Solutions \\
\hline
\end{tabular}

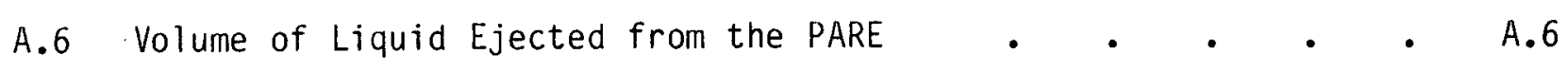

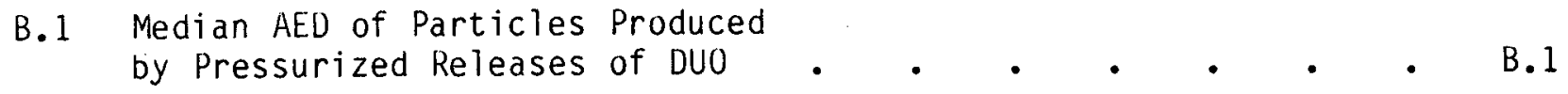


B.2 Median AED of Particles Produced by

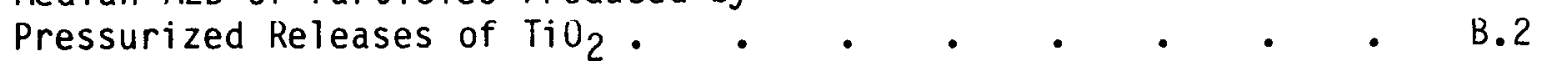

B.3 Median AED of Particles Produced by $\mathrm{TiO}_{2}$ Powder Releases Above Chamber (PRAC)

B.4 Median AED of Particles Produced by Pressurized Releases of Uranine Solutions

B.5 Median AED of Particles Produced

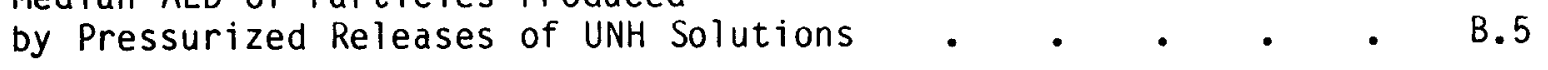


SUMMARY AND CONCLUSIONS

Pacific Northwest Laboratory conducted experiments to measure aerosols generated by pressurized releases of powders and liquids. Data from these experiments will be used in developing models to predict accidental airborne releases. The mass airborne and particle size distribution of the aerosols generated by pressurized releases were measured as a function of source size and chamber pressurization level. Powder and liquid sources were placed in a container, pressurized to selected levels, then released to the ambient air by rapid depressurization through ruptured discs.

Two $\mathrm{TiO}_{2}$ and DUQ masses $(10 \mathrm{~g} \mathrm{~g}$ and $350 \mathrm{~g})$, and two uranine and UNH solution volumes $\left(100 \mathrm{~cm}^{3}\right.$ and $\left.350 \mathrm{~cm}^{3}\right)$, were released from a pressurized chamber at 50,250 , or 500 psig. Releases were mąde in the Radioactive Aerosol Release Tank (RART) which has a volume of $20 \mathrm{~m}^{3}$--about the size of a small room. The airborne material was collected by high volume samplers. Particle size distributions were calculated from samples collected using a high volume cascade impactor.

Pressurization level and source size were significant variables for the airborne powder releases, with pressure having a more pronounced effect. Releases from the two types of powders were comparable. The average weight percent airborne for these powders ranged from about $2 \%$ to $24 \%$. Although there was less airborne mass from the $100-\mathrm{g}$ powder source, the percentage airborne was greater than from the $350-g$ powder source.

Liquid mass releases were a function of pressure, but for this experimental configuration (rupture discs above the liquid) the source volume did not appear significant. The average weight percent of liquid source that became airborne ranged from $0.0004 \%$ to $0.15 \%$, and as with powder, represented a larger fraction of the smaller sources.

Other findings were:

- All releases produced a significant fraction of particles $10 \mu \mathrm{m}$ and less in median aerodynamic equivalent diameter (AED). These are considered respirable.

- Powder aerosols ranged from an average of 5 um to 19 um AED.

- Liquid aerosols ranged from an average of $2 \mu \mathrm{m}$ to $29 \mu \mathrm{m}$ AED.

- Uranine solutions produced the finest, most homogeneous aerosols.

Results of these experiments are now being used to develop models to estimate the airborne particulate material generated by the energy in these events.

Some suggestions for future pressurized release investigations are included in this report. 
INTRODUCTION

Aerosol generation characteristics of accidental particle releases in nuclear fuel cycle facilities are being investigated at Pacific Northwest Laboratory (PNL). The work is sponsored by the U.S. Nuclear Regulatory Commission, Office of Nuclear Regulatory Research. Safety analys is reports and environmental impact statements must evaluate the consequence of postulated accidents in or involving the facility in question. During an accidental release from a nuclear fuel cycle facility the dominant pathway to man is usually through airborne particles, so it is necessary to determine an aerosol source term (i.e., the quantity of material initially airborne from an accident).

Assessments of the potential consequences of accidents are based on scenarios that define the sequence of largely inadvertent conditions that result in airborne releases. Typical events range from spilling the materials in free fall through air, to releases caused by fire and explosion. It is difficult to make reasonable assessments of accident scenarios, largely because information permitting such analysis is lacking or scattered in the literature. Our research has several directions: to define a range of accident conditions, to review available published information to assess the aerosol generation and behavior under these conditions, and to perform experimental studies to provide new data.

To give us an indication of the upper and lower limits of accidental airborne releases, we have suggested upper and lower boundary events. Free-fall spills in static air are considered a lower bound release event (Sutter et al. 1981) and releases of pressurized powders and liquids from ruptured containers are suggested as an upper bound event. This report describes a series of experiments performed to investigate aerosols generated by these releases. Such events are of concern and have occurred in the nuclear industry. An example of a pressurized release scenario happened in a plutonium oxide storage facility (Committee Report 1979). Presence of decomposition products and water in a can of plutonium oxide powder led to pressurization and subsequent rupture of the can and resulted in a plutonium release.

Data to calculate the release of pressurized powders and liquids from containers were not found in a literature review (Sutter 1982). The only information available to estimate the magnitude of this type of release has been based on estimations of airborne powder concentrations. Swain and Haberman (1961) reviewed data from nonnuclear sources and calculated that $33 \mathrm{mg} / \mathrm{m}^{3}$ was the maximum airborne powder concentration a few minutes after an accident. Castleman, Horn and Lindauer (1969) generated fine particles using an exploding wire technique and found concentrations as high as $71 \mathrm{mg} / \mathrm{m}^{3}$ plutonium a few minutes after generation. Mishima (1975) anticipated an upper concentration of $100 \mathrm{mg} / \mathrm{m}^{3}$ for quasi-stable, accident-generated, airborne concentrations of dry powders. 
Because the literature review did not reveal adequate information to characterize pressurized releases, an experimental program was implemented. Experimental pressurized releases of powders and liquids were conducted in static air in an enclosure, and the airborne mass and particle size distribution determined. We measured pressurized releases of two powders, titanium dioxide $\left(\mathrm{TiO}_{2}\right)$ and depleted uranium dioxide (DUO) and two liquids, sodium fluorescein solution (uranine) and uranyl nitrate hexahydrate (UNH), at three pressures 50, 250, and 500 psig. Abbreviations for the compounds are used throughout this report to avoid confusing uranine and uranium. Data from these experiments will be used in ongoing work to develop release models based on physical parameters. Pressurized releases resulting from closed containers that rupture when exposed to excessive heat (i.e., fires) are not considered in this study. Liquid spray data can be used to evaluate pressurized releases of liquids with the failure point below the liquid level.

General experimental procedures and the results are discussed in the main portion of the work. This study is part of a continuing experimental program to measure accident-generated particulate materials. Therefore, the same source materials, sampling procedures, and sample analys is techniques used in an earlier work were employed here. These were described in detail by Sutter (1981) in a report documenting free fall spill experiments. Airborne mass measurements are in Appendix A. Appendix B lists the median aerodynamic equivalent diameters. 
EXPERIMENTAL PROCEDURES

Experiments were performed to determine the amount of airborne material and the aerodynamic particle size of the aerosols generated by releases of pressurized powders and liquids in static air. We were interested in determining the airborne mass generated during the release event rather than the time-dependent behavior of the aerosol. Through our experiments we identified bounding conditions (i.e., the lower and upper limit of the airborne release). Midpoint values were measured, but a study of a wide range of experimental parameters was not within the scope of this project. Experiments were limited by the availability of equipment and planning decisions. We are interested in indoor releases, so most of the experiments were performed in a room-size enclosure.

We used a matrix of experiments using $\mathrm{TiO}_{2}$ and DUO powders and uranine and UNH liquids to investigate the effect of source size, density, and chamber pressure on the airborne release. We ran experiments at thręe pressures ${ }_{3}(50$, 250 , and $500 \mathrm{psig}$ ), with $100 \mathrm{~g}$ and $350 \mathrm{~g}$ of powder or $100 \mathrm{~cm}^{3}$ and $350 \mathrm{~cm}^{3}$ of liquid. Radioactive DUO and UNH were used because they are found in nuclear fuel cycle facilities and are considered suitable surrogates for $\mathrm{PuO}_{2}$ powder and plutonium solutions. This was important because the information from these experiments is being developed for use in evaluating hazards in nuclear fuel cycle facilities.

\section{EXPERIMENTAL CHAMBER}

A chamber called the PARE (Pressurized Airborne Release Equipment) was designed and fabricated for use in these experiments. The PARE, shown schematically in Figure 1, is approximately $800 \mathrm{~cm}^{3}$ in volume and can be loaded with a maximum of $524 \mathrm{~cm}^{3}$ of powder. $\mathrm{TiO}_{2}$ is a light, loosely compacted powder and $350 \mathrm{~g}$ filled the chamber. This established the maximum powder mass of both $\mathrm{TiO}_{2}$ and DUO used in the experiments; $100 \mathrm{~g}$ was the second source quantity used.

After pressurization with air to a preselected experimental level, material contained in the PARE can be released explosively by the rupturing of discs. A rupture disc is a thin, circular, metallic membrane clamped between metal flanges. The complete assembly is called a safety head, because it is usually used as a relief valve to protect a system from excessive pressure. The discs are constructed to rupture at a specified pressure. The PARE uses a double disc safety head to give precise control of the chamber pressure at the time of rupture. With this disc arrangement the intermediate chamber pressure can be varied to keep the pressure difference across the disc within safe limits. To cause the powder release, a solenoid valve is opened letting the intermediate chamber depressurize. The pressure difference across the lower disc quickly becomes too great and the disc ruptures, causing the upper disc to rupture microseconds later. 


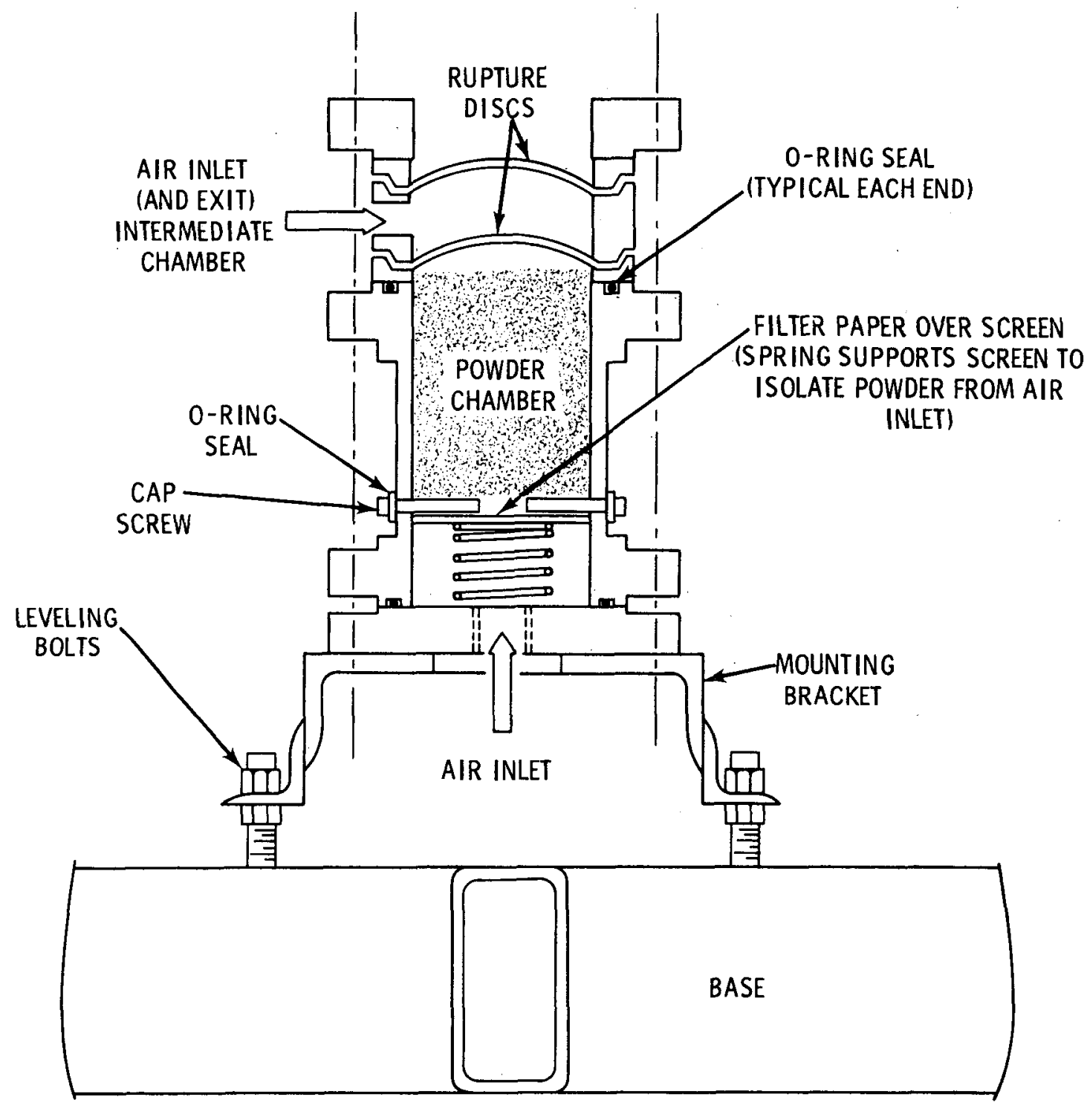

FIGURE 1. PARE, Pressurized Airborne Release Equipment

PROCEDURE

The general sampling procedure for conducting the experiments, shown in Figure 2, was to pressurize both chambers and then depressurize the intermediate chamber thus ejecting the powder. Samplers were immediately turned on and particle laden air pulled onto filters, as indicated by the solid arrows in Figure 2. Clean air exits from the rear as indicated by the light arrows. Figure 3 is a photo of one of the experiments showing a typical powder release. 


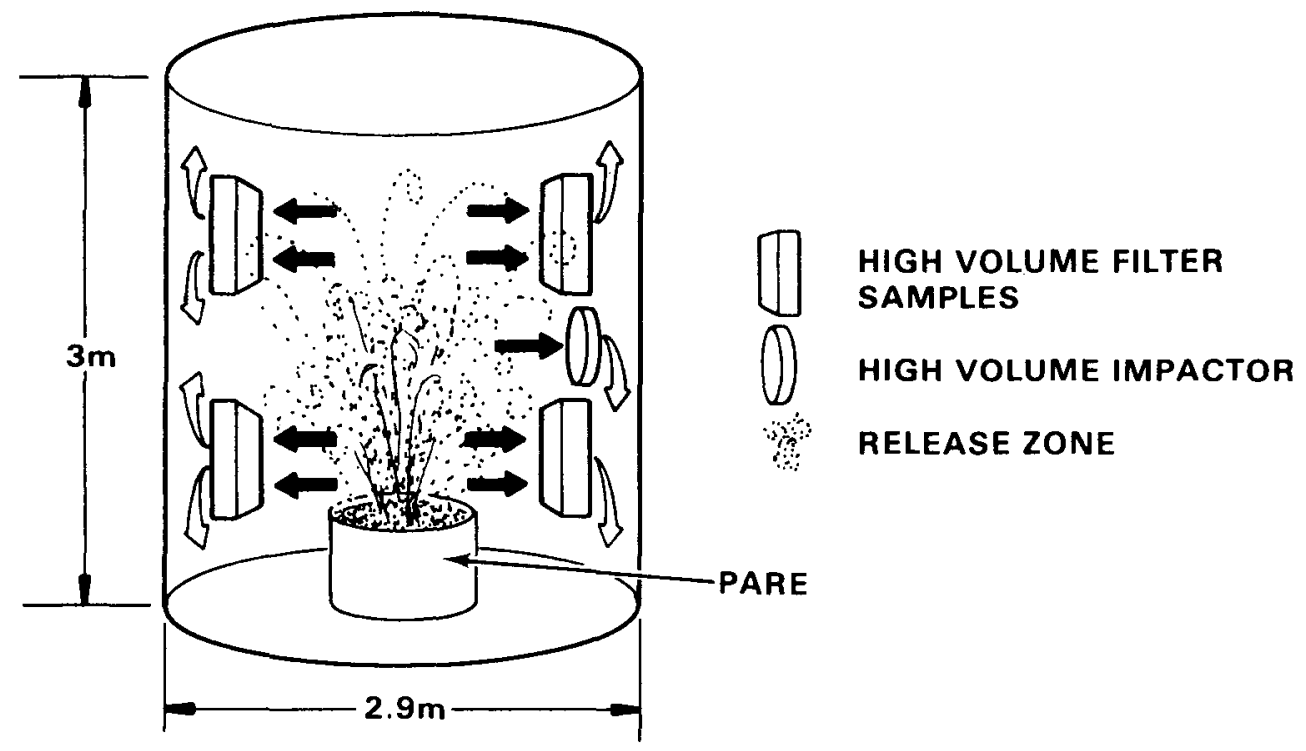

FIGURE 2. Sampling for a Pressurized Release with High Volume Samplers

The experiments were conducted in a cylindrical enclosure called the Radioactive Aerosol Release Tank (RART). It is a stainlegss steel vessel approximately $3 \mathrm{~m}$ high and $2.9 \mathrm{~m}$ in diameter with a $20-\mathrm{m}^{3}$ volume, about the size of a small room.

Figure 2 shows four high volume samplers at the 1-m and 2-m level and one high volume cascade impactor at the $1.5-\mathrm{m}$ level, equipped with appropriate glass fiber filters, as they were used to sample aerosol. Eight RART volumes of air were pulled through the samplers in a 30-minute run. After 30 minutes, 99\% of the airborne material should be collected since the aerosol concentration decayed exponentially. Background samples after early runs showed that in experiments generating large amounts of airborne powder, $1.5 \%$ of the aerosol mass could remain airborne after sampling. Therefore, two additional high volume samplers were included and sampling time increased to one hour. Analys is of overnight deposition samplers placed in the RART after the high volume sampling established that less than $1 \%$ of the collection remained airborne. [Some of the airborne material settles during the sampling. As in the case of the free-fall spills data (Sutter 1981), corrections can be made for this settling loss, but they are not extremely significant.]

Experimental pressures were monitored with a transducer indicator which was calibrated before use to an accuracy of $\pm 0.5 \%$. The chamber pressure level was displayed as a digital readout. 


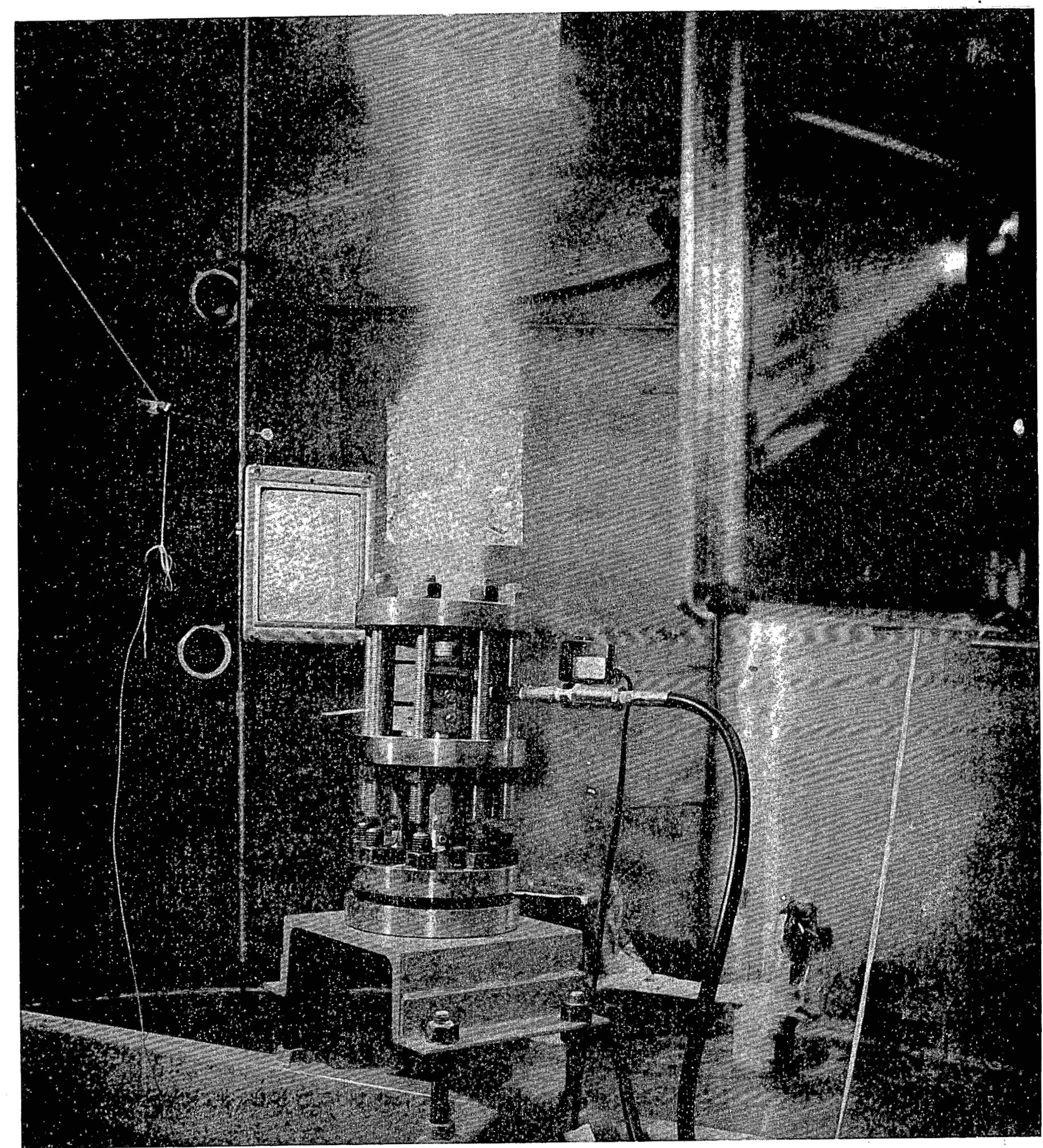

FIGURE 3. PARE Experiment 
Experimental Design

The experimental matrix was designed for analysis of variance (AOV) techniques. AOV divides the total variation of the dependent variables (mass airborne) into the variation from:

- factors under investigation

- interaction between factors under investigation

- experimental error.

The variation of the factors under investigation is compared to the experimental error to reach a conclusion regarding the uncertainty of the results. Replicate experimental runs are included at all levels.

\section{Wall Deposition}

In some of the initial experiments, foil squares were placed on portions of the RART walls to collect aerosol deposition samples. Our work focuses on measuring airborne material so sampling of wall deposition was limited.

Sample Analysis

Uranine aerosols collected on the filters were dissolved in water and analyzed by fluorometry. Dilutions of a stock solution representing different concentrations were made and the results read on a fluorometer. The lower detection limit is about $1 \times 10^{-9} \mathrm{~g} / \mathrm{cm}^{3}$. The results were plotted and the unknown sample values read from this plot. We formulated equations for the plot at each of the four fluorometer ranges and used these for calculating results. $\mathrm{R}^{2}$ (correlation between observed and predicted values) values approached one, indicating a good fit for the standard curve at all attenuations.

We dissolved filter samples containing collected uranium aerosols in acid and analyzed the samples using laser fluorometry. This method employs a pulsed nitrogen laser to excite uranium in a solution containing a pyrophosphate reagent. The fluorescent signals are amplified and integrated, and the results are displayed on a meter. We analyzed standards that were prepared using our DUO results and established that the error was less than $10 \%$.

\section{OTHER POWDER RELEASES}

Initial experiments revealed an enclosure effect from the high pressure jetting powder out and impacting it on the RART ceiling. This led us to the question of how high an unrestricted release would go. Two experiments (350 g $\mathrm{TiO}_{2}$ at 50 and 1000 psig) were conducted outdoors and the release height was measured using triangulation methods. The release volume was estimated from high speed photographs. 
Unpressurized powder above a pressurized chamber can be involved in an accident. The PARE was modified as shown in Figure 4 so powder could be placed above the chamber. Only a limited number of these PRAC (Powder Release Above Chamber) experiments were performed since the PARE type event is considered more important in our accident scenarios. $\mathrm{TiO}_{2}$ was released once at each pressure and source size level.

\section{LIQUID RELEASES}

The PARE was modified as shown in Figure 5 to allow pressurized liquid releases from the same configuration used in powder releases. Experiments with two source quantities $\left(100 \mathrm{~cm}^{3}\right.$ and $\left.350 \mathrm{~cm}^{3}\right)$ at three pressures $(50,250$, and 500 psig) were completed using uranine and UNH.

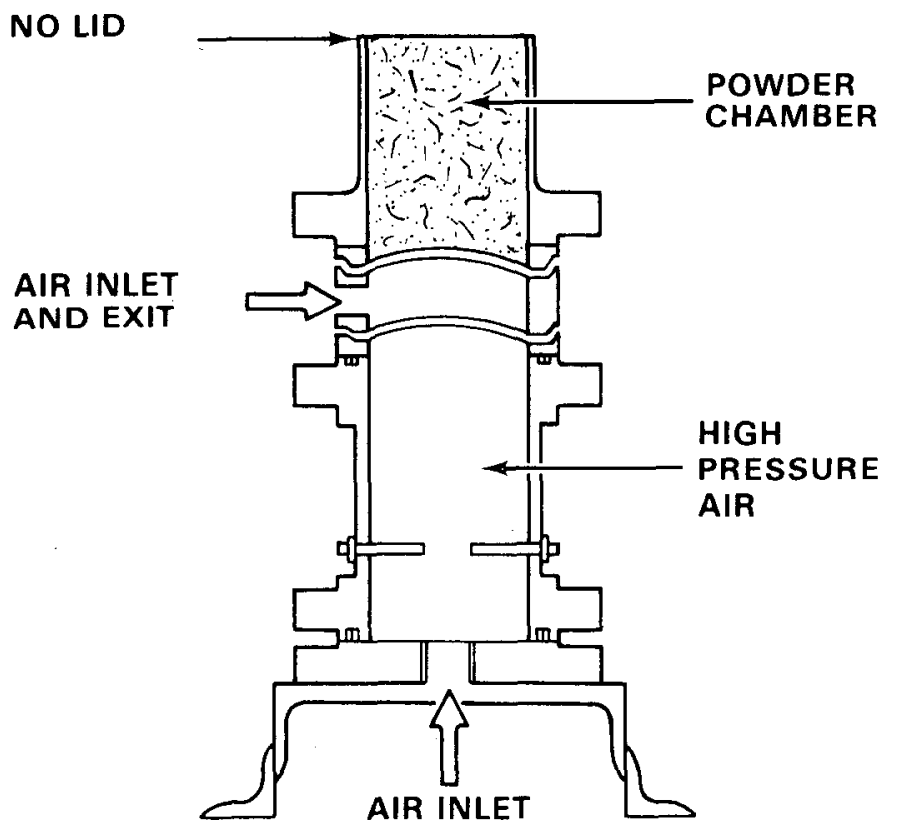

FIGURE 4. PARE Modification for Powder Release Above Chamber (PRAC) Experiments 


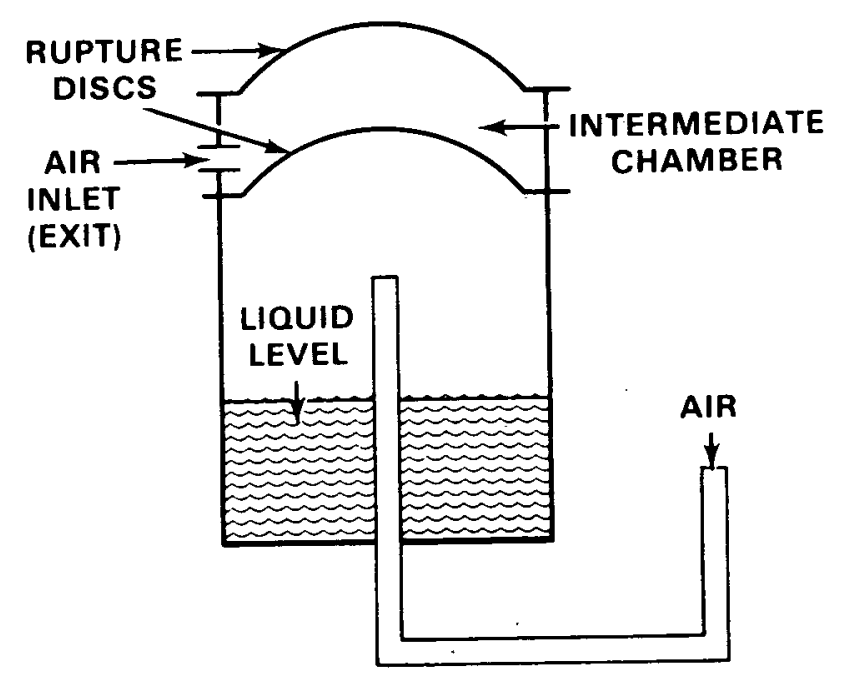

FIGURE 5. PARE Modification for Pressurized Liquid Release Experiments 
RESULTS AND DISCUSSION

Included in the following discussion are results of the high volume sampling of the powder and liquid release experiments. These results will be used to develop models which will estimate airborne releases of accident-generated aerosols. These models, which are to be based on physical parameters, will be described in a later report.

A complete listing of the measured release values for the mass airborne is in Appendix $A$ and values for particle size are in Appendix $B$.

POWDER RELEASES -- PARE EXPERIMENTS

PARE releases in the RART were the primary thrust of the pressurized powder experiments. In the following paragraphs we discuss measurements of the total mass airborne, weight percent of source powder airborne, and particle size distribution, resulting from pressurized powder releases.

Mass Airborne

The average powder mass airborne from replicate runs (for individual run results see appendix) of $\mathrm{TiO}_{2}$ and DUO release experiments are listed in Table 1 and plotted in Figure 6. Two exploratory experiments using $\mathrm{TiO}_{2}$ at 1000 psig are included.

TABLE 1. Average Mass Airborne from Pressurized Powder Releases

\begin{tabular}{|c|c|c|c|c|}
\hline \multirow{2}{*}{$\begin{array}{c}\text { Pressure, } \\
\text { psig }\end{array}$} & \multicolumn{2}{|c|}{$350 \mathrm{~g}$ Source } & \multicolumn{2}{|c|}{$100 \mathrm{~g}$ Source } \\
\hline & $\mathrm{Ti}_{2}, \mathrm{~g}$ & DU0, g & $\mathrm{TiO}_{2}, \mathrm{~g}$ & DU0, \\
\hline 1000 & & & & \\
\hline 500 & & 30.2 & & 19.8 \\
\hline 250 & 18.3 & 20.5 & 18.2 & 13.0 \\
\hline 50 & 3.3 & 6.9 & 4.4 & 3 \\
\hline
\end{tabular}

The results in Table 1 for $\mathrm{TiO}_{2}$ make it appear that the release quantity was independent of source quantity. A review of the experimental data, however, suggest that this is an effect of time. Two significantly different releases were averaged. Five exploratory experiments were performed in the summer to check out the PARE apparatus, and then further experiments were postponed because of other work requirements. As was found in the free fall spill experiments (Sutter 1981), there was a time effect. Later runs had higher levels of $\mathrm{TiO}_{2}$ than did early runs. Replicate runs yielding larger releases were made at lower temperatures, $14^{\circ} \mathrm{C}$ to $19^{\circ} \mathrm{C}$, and early runs at as much as $23^{\circ} \mathrm{C}$. 


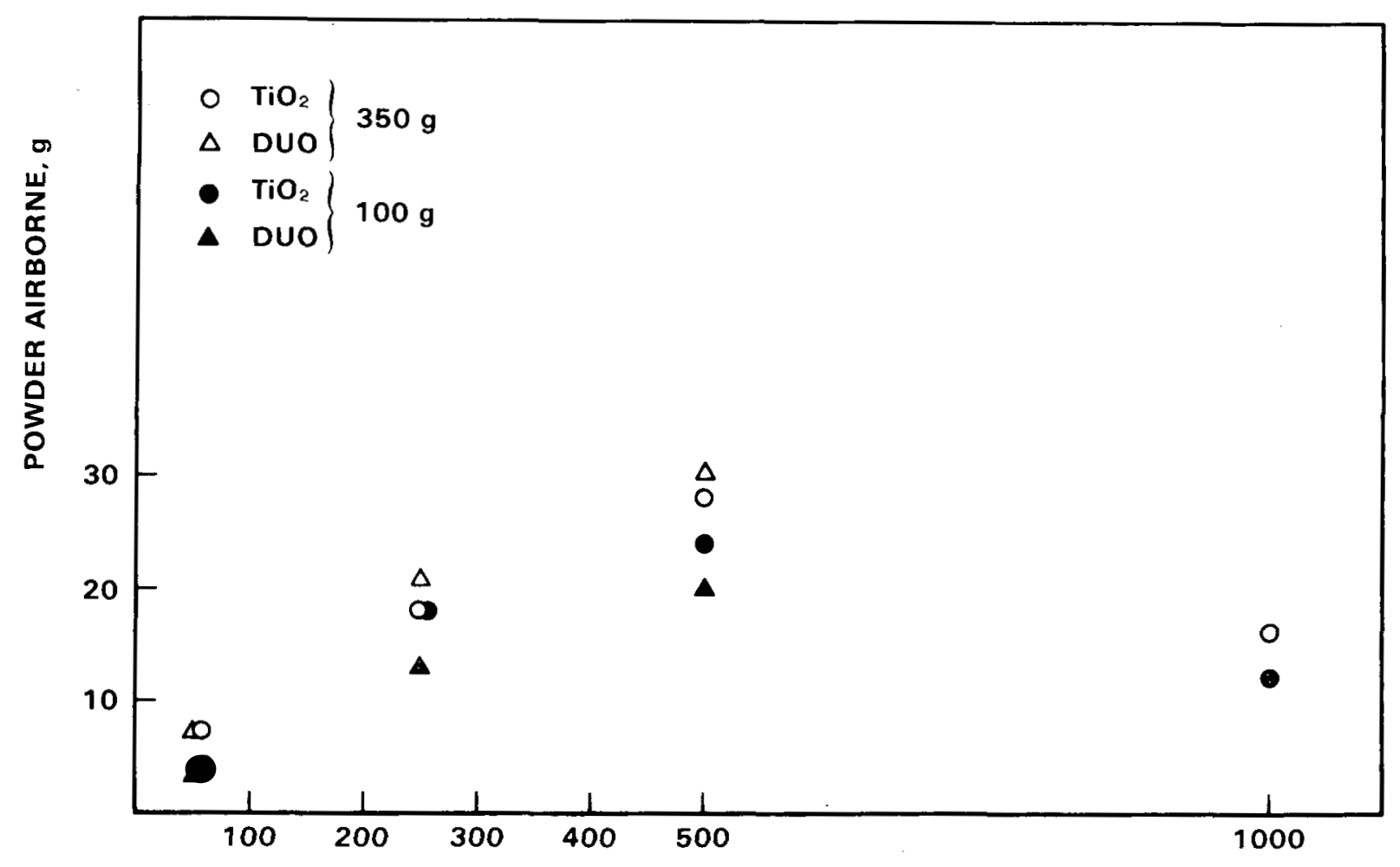

PRESSURE, psig

FIGURE 6. Mass Airborne from the Pressurized Release of Two Powders

The average mass airborne from the PARE experiments increased as a function of pressure for both $\mathrm{TiO}_{2}$ and DUO powders. This increase continued up to 500 psig as shown in Figure 6 . The 1000 psig exploratory runs using both source quantities of $\mathrm{TiO}_{2}$ had a lower measured mass airborne than the 500 psig runs. This is attributed to an enclosure effect because the powder impacted on the center of the ceiling where a portion was retained. After impacting on the ceiling, the remainder spread to the sides of the RART where there was further impaction, and consequently, less of the release was in the airborne fraction. Because the focus of our work is to identify the maximum airborne release, runs at 1000 psig were not continued. Ceiling impaction was a factor at all pressures, however.

A material balance would be helpful to explain the above discrepancies, but attempts made to collect the ejected powder were not satisfactory. The ejected material was so widely dispersed that the technician was unable to recover it completely. For example, during the first run at 250 psig, 10 grams became airborne, but. only $288 \mathrm{~g}$ were recovered from the RART. This leaves $50 \mathrm{~g}$ of the $350 \mathrm{~g}$ source unaccounted for. 
Chamber pressure and source quantity were significant variables for aerosol generation for both powders, with the pressure having a more pronounced effect. Release from the different types of source powders were comparable for the same experimental parmeters. Each high volume sampler had about the same mass collection, indicating that the aerosol achieved a fairly uniform distribution in the RART.

There was no pressure rise evident in the RART. This was anticipated since we calculated the $\triangle P$ using the expression:

$$
\Delta P=\frac{V_{P}}{V_{R}}\left(\frac{T a}{273^{0} K}\right) P_{g}
$$

where

$$
\begin{aligned}
& \Delta P=\text { pressure rise, psi } \\
& V_{P}=\text { PARE volume } \\
& V_{R}=\text { RART volume } \\
& T_{a}=\text { ambient temperature, }{ }^{\circ} \mathrm{K} \\
& P_{g}=\text { pressure of compressed gas, psi. }
\end{aligned}
$$

Total volume of the PARE is about $862 \mathrm{~cm}^{3}\left(812 \mathrm{~cm}^{3}\right.$ for the chamber and an additional $50 \mathrm{~cm}^{3}$ for the dome shaped rupture disc). The RART volume is about $2.0 \times 10^{7} \mathrm{~cm}^{3}$, so even for the empty chamber at $1000 \mathrm{psig}$ the $\Delta P$ is $0.05 \mathrm{psi}$.

Weight Percent Airborne

The weight percent of source that becomes airborne is a direct method used to estimate releases, so our data (average of replicate runs) for powder are presented as weight percents in Table 2 and plotted in Figure 7.

The weight percent of the source that became airborne in the enclosure was larger for the smaller sources. The weight percent of airborne source at different pressures was comparable for both powders. The maximum average value of $24 \%$ might be used to make a conservative estimate of pressurized powder

\begin{tabular}{|c|c|c|c|c|}
\hline $\begin{array}{c}\text { Pressure, } \\
\text { psig }\end{array}$ & $\frac{350 \mathrm{~g}}{\mathrm{TiO}}$ & $\frac{\text { Source }}{\text { DUO }}$ & $\frac{100 \mathrm{~g}}{\mathrm{TiO}_{2}}$ & $\frac{\text { Source }}{\text { DU0 }}$ \\
\hline 1000 & 5 & & 12 & \\
\hline 500 & 8 & 9 & 24 & 20 \\
\hline 250 & 5 & 6 & 18 & 13 \\
\hline 50 & 2 & 2 & 4 & 4 \\
\hline
\end{tabular}
releases within pressure limits used in this work. It is also possible that in an unconfined experiment, the weight percent airborne might increase as pressure is increased.

TABLE 2. Average Weight Percent Airborne from Pressurized Powder Releases 


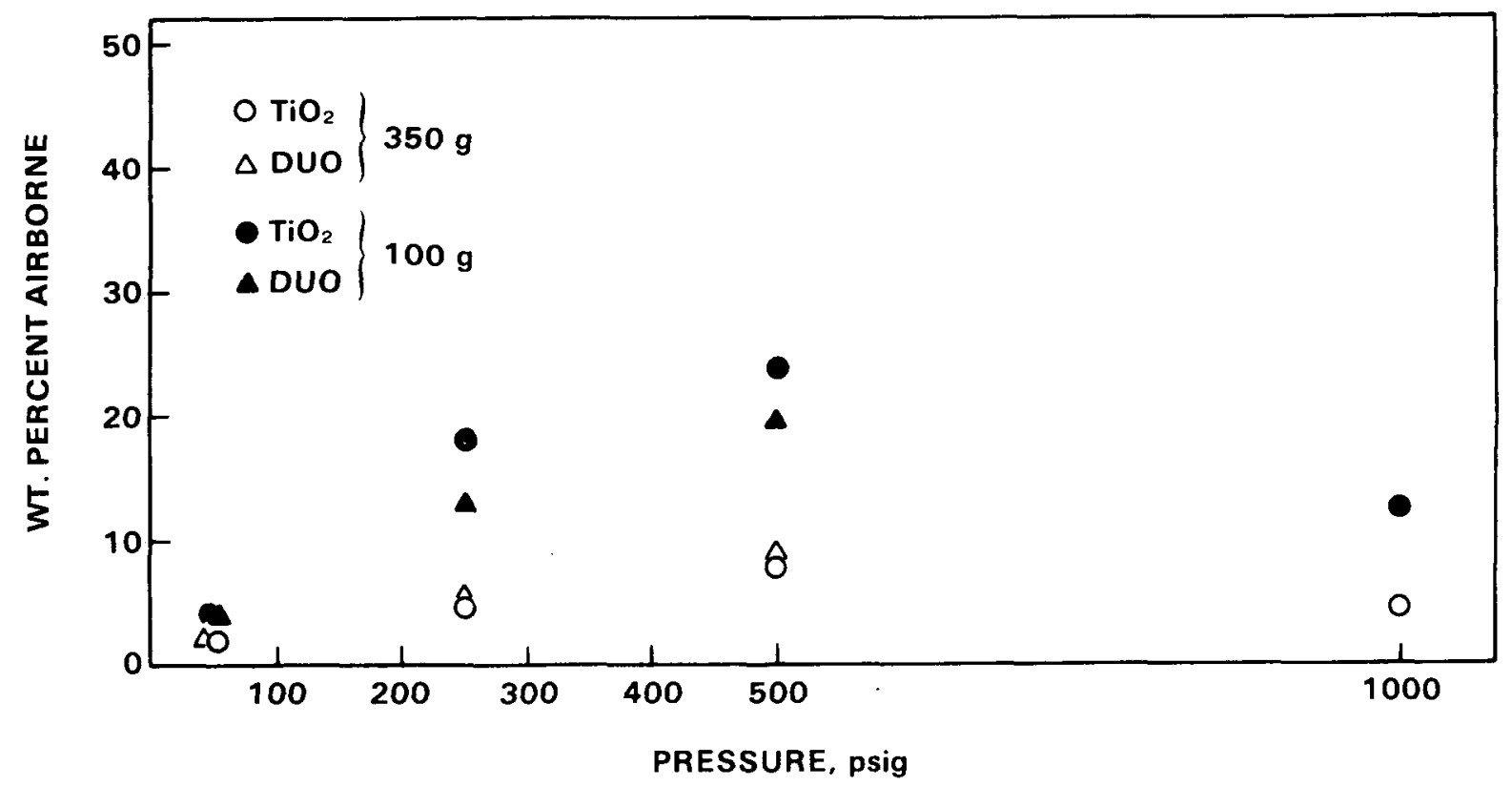

FIGURE 7. Average Weight Percent of Powder Airborne as a Function of Pressure

Particle Size Distribution

The median aerodynamic diameters for the particles for all experiments are listed in Appendix $B$. The average values from replicate, powder-release experiments are shown in Table 3. These powders are similar in terms of diameter.

TABLE 3. Average Median AED of Particles Generated by Pressurized Powder Releases, um

Chamber

\begin{tabular}{|c|c|c|c|c|}
\hline \multirow{2}{*}{$\begin{array}{c}\text { Pressure, } \\
\text { psig }\end{array}$} & \multicolumn{2}{|c|}{$350 \mathrm{~g}$} & \multicolumn{2}{|c|}{$100 \mathrm{~g}$} \\
\hline & $\mathrm{TiO}_{2}$ & DUO & $\mathrm{TiO}_{2}$ & DUO \\
\hline 500 & 14 & 16 & 5 & 14 \\
\hline 250 & 14 & 15 & 10 & 11 \\
\hline 50 & 18 & 19 & 8 & 19 \\
\hline
\end{tabular}

Some of the calculated diameters are beyond the range of the impactor sampler and were estimated by extrapolation of the data. These particles are probably agglomerates since they are larger than the source powder particle size. The confined release in the enclosure would not give opportunity for 
dispersion of agglomerates. It has been observed that the effectiveness of dispersion from this type of event is limited, and therefore, results in larger mean particle sizes (Seefeldt 1977). Seefeldt concluded that an accidental explosion will have the greatest consequence in the absence of confinement because the particle sizes would be smaller.

The geometric standard deviation $(\sigma g)$ of the particle size distribution is a measure of the aerosol homogeneity. These values ranged from 1.9 to 14 for. the PARE powder experiments indicating a disperse particle size distribution for the aerosols. DUO aerosols were the most uniform with og values ranging from 1.9 to $4.8 ; \mathrm{TiO}_{2}$ ranged from 4.1 to 14 .

All of the releases generated a significant fraction of particles with diameters $10 \mu \mathrm{m}$ and less, particles that can be inhaled and retained in the lung. This portion ranged from $25 \%$ of the source mass for a DU0 release at 50 psig to $72 \%$ for $100 \mathrm{~g} \mathrm{TiO}_{2}$ released at $500 \mathrm{psig.} \mathrm{Respirable} \mathrm{particles}$ represented from 1 to $21 \%$ of the aerosol.

\section{Wall Deposition}

An enclosure effect can be anticipated from this event. During early runs we placed aluminum squares on the RART walls to collect aerosol deposition samples. Table 4 shows the total wall deposition calculated from replicate $\mathrm{TiO}_{2}$ runs and the percent of source deposited. The largest fraction of the ejected material fell to the floor of the RART.

TABLE 4. Calculated Average $\mathrm{TiO}_{2}$ Wall Deposition

\begin{tabular}{|c|c|c|c|c|}
\hline & $350 \mathrm{~g}$ & ource & $100 \mathrm{~g}$ & Source \\
\hline Pressure & $\mathrm{g}$ & $\%$ & $g$ & $\%$ \\
\hline 500 & 2.25 & 0.6 & 0.98 & 0.98 \\
\hline 250 & 2.31 & 0.7 & 1.14 & 1.14 \\
\hline 50 & 0.94 & 0.3 & 0.16 & 0.16 \\
\hline
\end{tabular}

About $1 \%$ of the source was deposited on the walls in all experiments. The presence of walls can cause two effects: 1) the trajectory of the initial impact is shortened and this may eliminate added shear stresses on the particles that could cause more airborne fines, and 2) the impact itself probably creates some aerosol that would not be generated in the unrestricted path. These two effects counterbalance one another and their net contribution is rikely to be small.

\section{Powder Ejected}

At 500 and 250 psig, all the powder was ejected from the PARE. At 50 psig, some powder sometimes remained in the PARE. Based on the amount recovered from the PARE, 77 to $97 \%$ of the source powder could be ejected from the PARE during a release at 50 psig. 
The masses airborne from the PRAC experiments are listed in Appendix $A$, and median particle sizes in Appendix $B$. Figure 8 is a plot of the mass releases. It appears from the plot that a maximum release would be about $38 \mathrm{~g}$ for this configuration.

The venting of pressurized gases through unpressurized powder resulted in an airborne mass ranging from 1.2 to 2.3 times greater than corresponding releases from the PARE, as shown in Table 5. Median particle sizes ranged from 7 to $15 \mu \mathrm{m}$, similar to that from PARE releases.

Because we consider the PARE type release (pressured powder and container) more important in accident scenarios, this work was limited to a few exploratory experiments.

POWDER RELEASES -- OUTDOOR TESTS

Two outdoor tests measured the plume height and volume produced by an unrestricted PARE release of $350 \mathrm{~g} \mathrm{TiO}_{2}$ powder at 50 and $1000 \mathrm{psig.} \mathrm{Data}$ generated from these tests are shown in Table 6 . Plume heights measured using

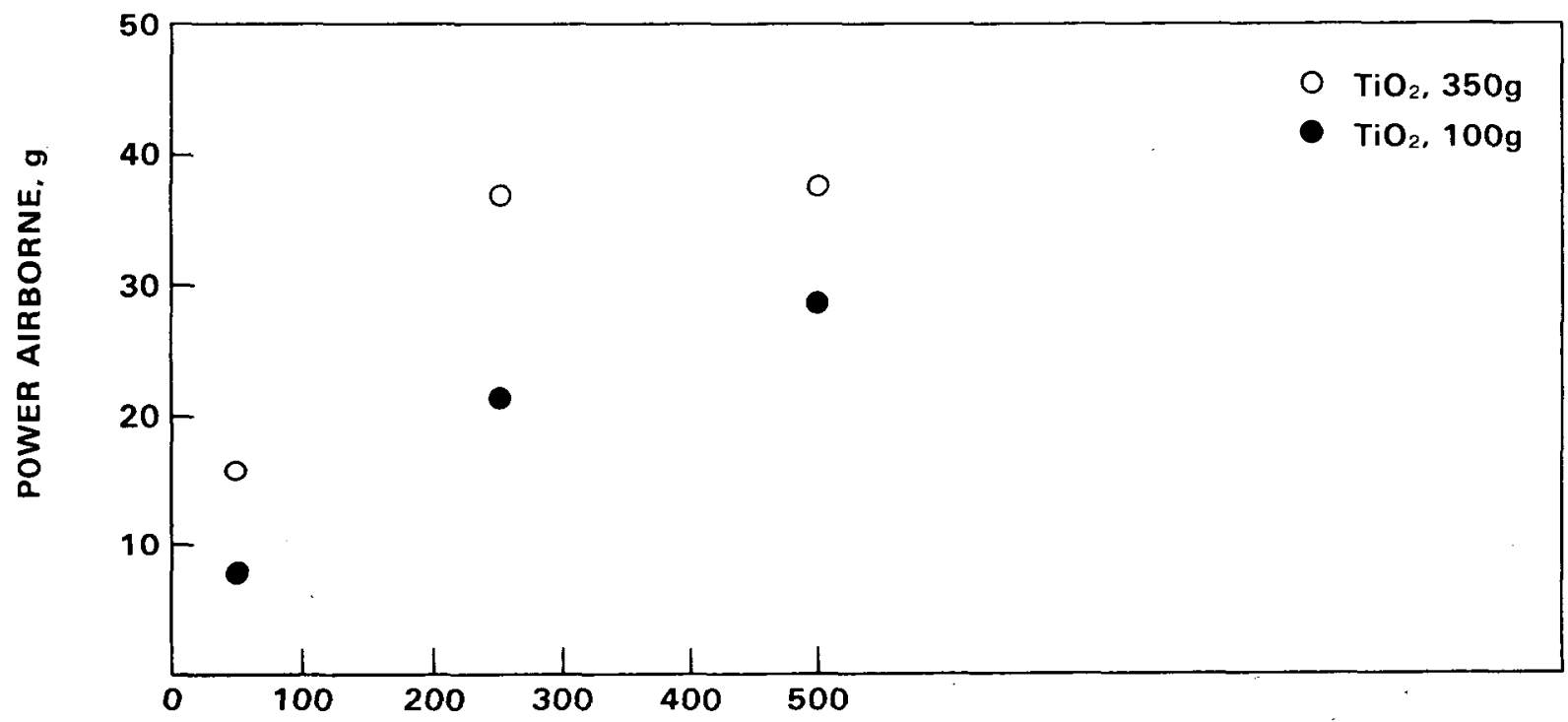

PRESSURE, psig

FIGURE 8. Mass Airborne from PRAC Experiments 
TABLE 5. Comparison of PARE and PRAC Releases

\begin{tabular}{|c|c|c|c|c|c|c|}
\hline \multirow[b]{2}{*}{ Pressure } & \multicolumn{2}{|c|}{$350 \mathrm{~g} \mathrm{TiO}$} & \multirow[b]{2}{*}{$x$ Greater } & \multicolumn{2}{|c|}{$100 \mathrm{~g} \mathrm{TiO}$} & \multirow[b]{2}{*}{$x$ Greater } \\
\hline & PARE, $\mathrm{g}$ & PRAC, 9 & & PARE, $\mathrm{g}$ & PRAC, $\mathrm{g}$ & \\
\hline 500 & 27.8 & 38.2 & 1.4 & 24.1 & 28.7 & 1.2 \\
\hline 250 & 18.3 & 36.7 & 2.0 & 18.2 & 21.3 & 1.2 \\
\hline 50 & 7.4 & 16.9 & 2.3 & 4.4 & 8.2 & 1.9 \\
\hline
\end{tabular}

TABLE 6. Results of Unrestricted PARE Pressurized Powder Releases

\begin{tabular}{|c|c|c|}
\hline & & Releases \\
\hline Parameters & $50 \mathrm{psig}$ & $1000 \mathrm{psig}$ \\
\hline Plume height & $4.5 \mathrm{~m}$ & $10.7 \mathrm{~m}$ \\
\hline Plume volume & $2.2 \mathrm{~m}^{3}$ & $10 \mathrm{~m}^{3}$ \\
\hline Expelled from PARE & $-200 \mathrm{~g}$ & $350 \mathrm{~g}$ \\
\hline $\begin{array}{l}\text { Plume initial } \\
\text { calculated } \\
\text { concentration }\end{array}$ & $91 \mathrm{~g} / \mathrm{m}^{3}$ & $35 \mathrm{~g} / \mathrm{m}^{3}$ \\
\hline $\begin{array}{l}\text { Amount deposited } \\
\text { in } 2.25 \mathrm{~m} \text { radius } \\
\text { of PARE }\end{array}$ & $30 \mathrm{~g}$ & $2 \mathrm{~g}$ \\
\hline $\begin{array}{l}\text { Percent Expelled and } \\
\text { deposited near } \\
\text { PARE }\end{array}$ & 15 & $<1$ \\
\hline
\end{tabular}

triangulation techniques were 4.5 and $10.7 \mathrm{~m}$ for 50 and $1000 \mathrm{psig}$, respectively. Volumes listed in Table 6 were estimated from high speed photographs. Deposition samplers placed on the ground near the PARE were analyzed to determine the amount deposited in the immediate vicinity of the release.

There was no measurable windspeed at the $50-\mathrm{m}$ elevation during these outdoor tests, however, the release cloud drifted away. As anticipated, an unconfined event would have more severe consequences, going higher and further than a release in the enclosure. Even more important, if the amount collected in a $2.25-\mathrm{m}$ radius represents that not airborne, then the unconfined release can result in $100 \%$ airborne at a high pressure.

\section{LIQUID RELEASES}

The modified PARE equipment shown in Figure 5 was used for pressurized liquid releases. Experiments measured releases from two source volumes at 
three pressures. In the following paragraphs we discuss the measurements of mass airborne, weight percent airborne, liquid ejected, and particle size distribution resulting from pressurized releases of liquids.

Mass Airborne

The average from replicate runs of the solution mass airborne is listed in Table 7 and plotted in Figure 93 These values were calçulated using measured solution densities of $0.99 \mathrm{~g} / \mathrm{cm}^{3}$ for uranine, $1.54 \mathrm{~g} / \mathrm{cm}^{3}$ for UNH.

The mass airborne increased as a function of pressure for both uranine solutions and UNH. The source volume did not appear significant in determining the magnitude of the release. Releases were also lower than we had anticipated. High speed photography revealed that the release seemed to be a vaporization of the liquid caused by the rapid depressurization. The only noticeable release was a condensed vapor cloud. However, since uranine and UNH did become airborne, some surface disturbance had to occur to entrain the solutes. The differences in the mass airborne from the different volumes may be a result of experimental variability. These measured releases were in the same range for both solutions.

These results were low enough to suggest comparison with free fall spill releases (Sutter 1981). It can be suggested that airborne releases from the two accident types we have studied might be related. In other words the lowest pressurized release measurements could be similar to the higher release values from spills. This hypothesis was examined for both powders and liquids.

While verification of this hypothesis was not evident in powder experiments, a review of the liquid releases indicates a close match in results. Releases resulting from $3 \mathrm{~m}$ spills of $125 \mathrm{~cm}^{3}$ uranine and UNH were measured and found to be essentially the same as the release of $100 \mathrm{~cm}^{3}$ of pressurized liquid. All of these releases ranged from $3 \times 10^{-3}$ to $5 \times 10^{-3} \mathrm{~g}$. This close agreement might be coincidental. There are different stresses being placed on the liquid in the two types of experiments.

TABLE 7. Average Mass Airborne from Pressurized Liquid Releases

\begin{tabular}{|c|c|c|c|c|}
\hline & $350 \mathrm{~cm}^{3}$ & Source & $100 \mathrm{~cm}^{3}$ & Source \\
\hline $\begin{array}{c}\text { Pressure, } \\
\text { psig } \\
\end{array}$ & $\begin{array}{c}\text { Uranine, } \\
\mathrm{g}\end{array}$ & $\begin{array}{c}\text { UNH, } \\
\mathrm{g} \\
\end{array}$ & $\begin{array}{c}\text { Uranine, } \\
\mathrm{g}\end{array}$ & $\begin{array}{c}\mathrm{UNH}, \\
\mathrm{g}\end{array}$ \\
\hline 500 & 0.17 & 0.13 & 0.15 & 0.13 \\
\hline 250 & 0.03 & 0.05 & 0.06 & 0.08 \\
\hline 50 & 0.003 & 0.002 & 0.005 & 0.003 \\
\hline
\end{tabular}

Weight Percent Airborne

The weight percent of the source liquids that become airborne is listed in Table 8 and plotted in Figure 10. 


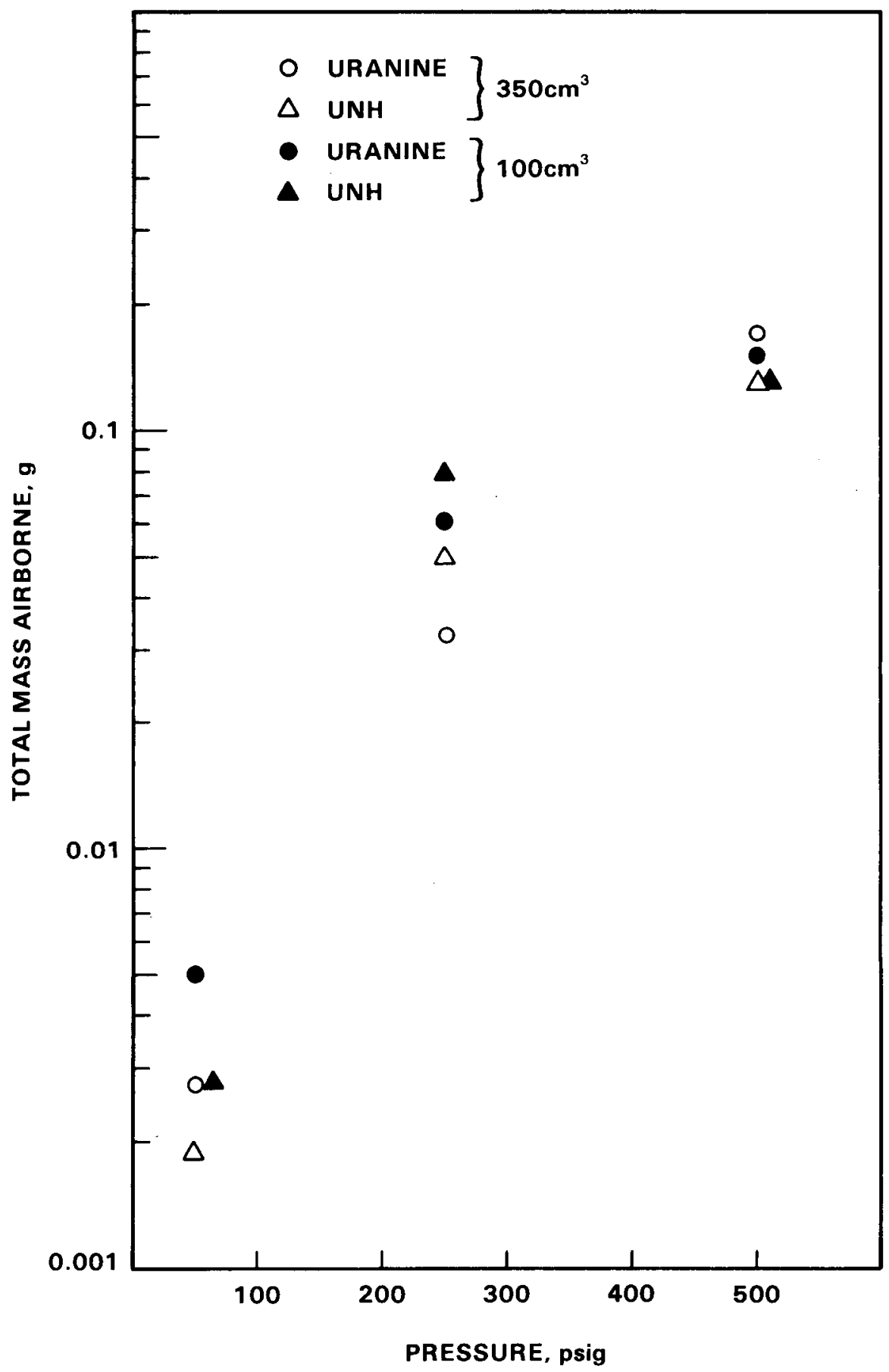

FIGURE 9. Mass Airborne from the Pressurized Release of Two Solutions 
TABLE 8. Average Weight Percent Airborne

from Pressurized Liquid Release

\begin{tabular}{|c|c|c|c|c|}
\hline $\begin{array}{l}\text { Pressure, } \\
\text { psig } \\
\end{array}$ & $\frac{350 \mathrm{~cm}^{3}}{\text { Uranine }}$ & $\begin{array}{c}\text { Source } \\
\text { UNH } \\
\end{array}$ & $\frac{100 \mathrm{~cm}^{3}}{\text { Uranine }}$ & $\begin{array}{r}\text { Source } \\
\text { UNH } \\
\end{array}$ \\
\hline 500 & 0.05 & 0.025 & 0.15 & 0.08 \\
\hline 250 & 0.01 & 0.01 & 0.06 & 0.05 \\
\hline 50 & 0.0008 & 0.0004 & 0.005 & 0.002 \\
\hline
\end{tabular}

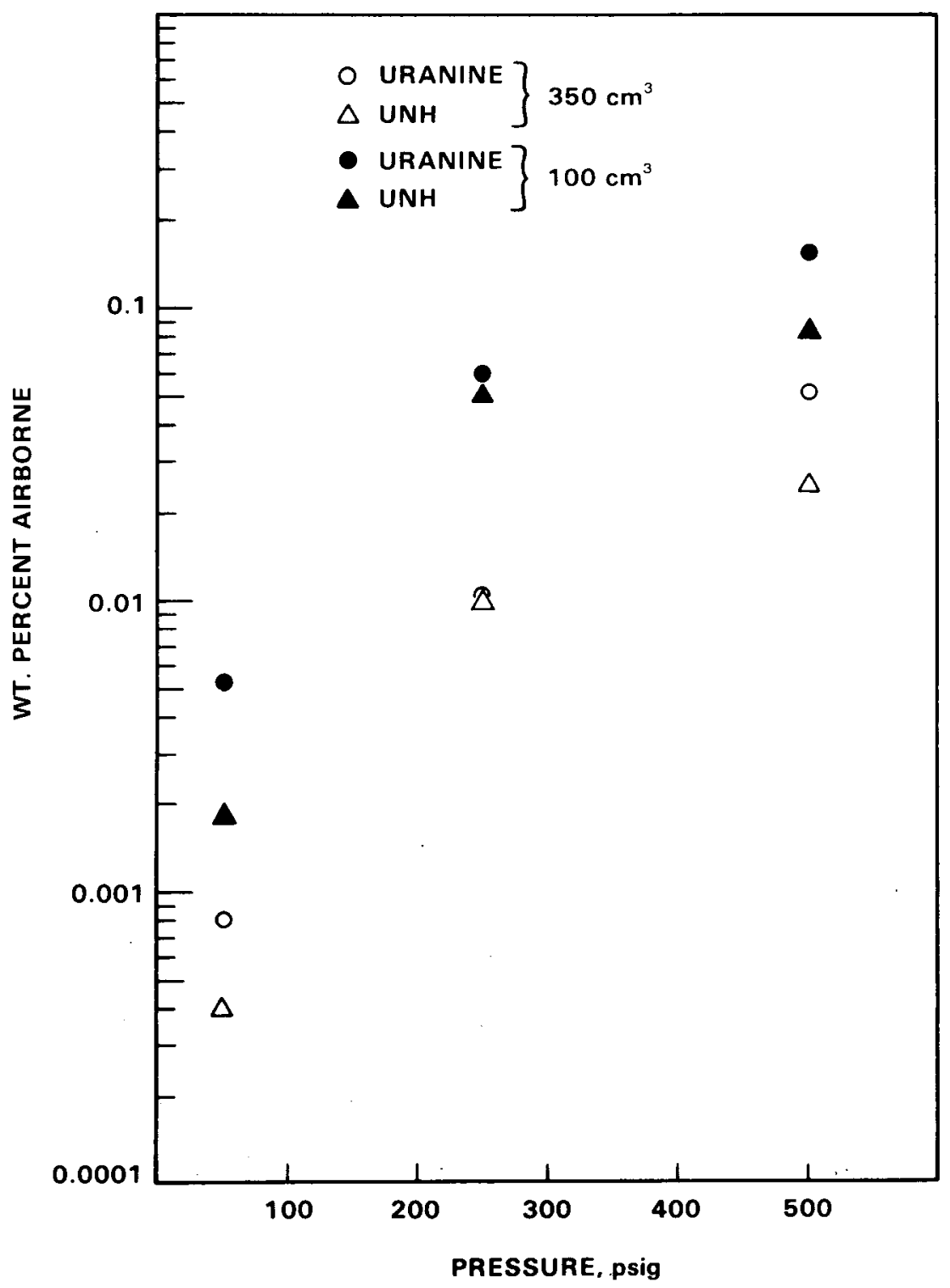

FIGURE 10. Average Weight Percent of Liquid Airborne as a Function of Pressure 
The weight percent of airborne material was comparable between the two solutions and increased with increasing pressure. The solution densities were measured and used to calculate the source mass for calculations of weight percent. At a density of $1.54 \mathrm{~g} / \mathrm{cm}^{3}$, the source UNH is 539 and $154 \mathrm{~g}$ for 350 and $100 \mathrm{~cm}^{3}$, respectively. Uranine solution density is $0.99 \mathrm{~g} / \mathrm{cm}^{3}$, which can be calculated to 347 and $99 \mathrm{~g}$ sources. The uranine source mass is about the same as that of the source powders, and can be used to compare the percent liquid and powder releases from the same source mass. This comparison is made in Table 9, using an average of the $\mathrm{TiO}_{2}$ and DUO values.

\section{TABLE 9. Comparison of Weight Percent of Source Mass Airborne from Pressurized Releases of Uranine Solution and Powder}

$\begin{array}{rllllll}\text { psig } & & \frac{\sim 350 \mathrm{~g} \text { Source }}{\text { Powder }} & & \frac{\sim 100 \mathrm{~g} \text { Source }}{\text { Uranine }} & & \frac{\text { Powder }}{\text { Uranine }} \\ 500 & & 8.5 & 0.05 & & 22.1 & 0.15 \\ 250 & & 5.6 & 0.01 & & 15.6 & 0.06 \\ 50 & & 2.1 & 0.0008 & & 4.2 & 0.005\end{array}$

The percent of powder released from the same source mass ranges from 150 to about 2600 times greater than comparable liquid releases. Dispersal mechanisms play a role in this difference. Small cavities in the powder bulk are filled with pressurized air. This acts to shatter the powder and energetically disperse it on release. The force acting on the liquid was rapid depressurization leading to vaporization and entrainment of the solution.

\section{Liquid Ejected}

In liquid releases a significant amount remains in the apparatus after the pressurized release. This amount was measured to determine the fraction of released material aerosolized. These values are listed in Table A.6 of the appendix. The average amount ejected is shown in Table 10, and the weight percent that became aerosolized is listed in Table 11.

TABLE 10. Average Amount of Liquid Ejected from PARE

\begin{tabular}{|c|c|c|c|c|c|c|c|c|}
\hline \multirow{3}{*}{$\begin{array}{c}\text { Pressure, } \\
\text { psig }\end{array}$} & \multicolumn{2}{|c|}{$350 \mathrm{~cm}^{3}$} & \multicolumn{2}{|c|}{ Source } & \multicolumn{2}{|c|}{$100 \mathrm{~cm}^{3}$} & \multicolumn{2}{|c|}{ Source } \\
\hline & \multicolumn{2}{|c|}{ Uranine, } & \multicolumn{2}{|c|}{ UNH, } & \multicolumn{2}{|c|}{ Uranine, } & \multicolumn{2}{|c|}{ UNH, } \\
\hline & $\mathrm{cm}^{3}$ & $\mathrm{~g}$ & $\mathrm{~cm}^{3}$ & $g$ & $\mathrm{~cm}^{3}$ & $\mathrm{~g}$ & $\mathrm{~cm}^{3}$ & $g$ \\
\hline 500 & 14 & 14 & 10 & 15 & 5 & 5 & 8 & 12 \\
\hline 250 & 8 & 8 & 7 & 11 & 6 & 6 & 6 & 9 \\
\hline 50 & 7 & 7 & 6 & 9 & 3 & 3 & 5 & 8 \\
\hline
\end{tabular}


TABLE 11. Average Weight Percent of Liquid Released that Became Aerosolized

\begin{tabular}{|c|c|c|c|c|}
\hline & $350 \mathrm{~cm}^{3}$ & Source & $100 \mathrm{~cm}^{3}$ & Source \\
\hline $\begin{array}{l}\text { Pressure, } \\
\text { psig }\end{array}$ & $\frac{\text { Uranine }}{\text { wt\% }}$ & $\frac{\mathrm{UNH}}{\mathrm{wt} \%}$ & $\frac{\text { Uranine }}{\text { wt\% }}$ & $\frac{\text { UNH }}{\text { wt\% }}$ \\
\hline 500 & 1.2 & 0.9 & 3.0 & 1.0 \\
\hline 250 & 0.4 & 0.5 & 1.0 & 0.09 \\
\hline 50 & 0.04 & 0.02 & 0.2 & 0.03 \\
\hline
\end{tabular}

Particle Size Distribution

Table 12 lists the average particle size distributions that were calculated from cascade impactor samples generated in replicate runs.

TABLE 12. Average Median AED of Particles Generated by Pressurized Liquid Releases, um

\begin{tabular}{|c|c|c|c|c|}
\hline \multirow{2}{*}{$\begin{array}{c}\text { Chamber } \\
\text { Pressure, } \\
\text { psig }\end{array}$} & \multicolumn{2}{|c|}{$350 \mathrm{~cm}^{3}$} & \multicolumn{2}{|c|}{$100 \mathrm{~cm}^{3}$} \\
\hline & Uranine & UNH & Uranine & UNH \\
\hline 500 & 4 & 16 & 4 & 14 \\
\hline 250 & 4 & 29 & 3 & 13 \\
\hline 50 & 2 & 4 & 2 & 7 \\
\hline
\end{tabular}

Releases of uranine solutions generated the finest, most uniform particles. Median diameters were $4 \mu \mathrm{m}$ and less, with $\sigma_{\mathrm{g}}$ values of 1.6 to 4 . These particles were predominantly (70 to $90 \%)$, in the respirable size range of $10 \mu \mathrm{m}$ and less. If there is a pressure or source quantity effect on the airborne particle size, the experimental variation between the 2 and $4 \mu \mathrm{m}$ values precludes a conclusion.

The UNH releases produced larger particle sizes and more polydispersed aerosols. Average median diameters ranged from 4 to $29 \mu \mathrm{m}$ and $\sigma_{\mathrm{g}}$ values from 2.5 to 7.5 . Fewer respirable particles ( $10 \mu \mathrm{m}$ and less) were generated, forming 34 to $76 \%$ of the aerosol.

The above particle size distributions were measured by using the cascade impactor samples, and may not be representative of the size distribution of the airborne liquid droplets. Significant evaporation of the droplets captured in the impactor could mean that the measured size distribution does not correspond to that of the actual airborne aerosol. This problem will be handled in the model development and discussed in that report. 
FUTURE WORK

The experiments discussed in this report are a continuation of our work investigating accident generated aerosols. Through our work, other potential research areas dealing with pressurized releases have been identified and are discussed in this section.

The behavior of liquid releases from pressurized containers, particularly, suggests the need for further experimental work. In our experimental configuration the pressurized air entered the bottom of the chamber, stabilized in the volume above the solution, and was released when the discs at the top of the chamber ruptured. The release seemed to be caused by the rapid depressurization vaporizing and entraining some of the liquid. Most of the solution, $85 \%$ or more, was retained in the PARE. The airborne release was low, (i.e., close to the level of spill releases). It would be appropriate to investigate a leak below the liquid level with pressure forcing the solution out. (This is a viable powder experiment also). These releases might be described satisfactorily using traditional spray relationships, and this could be confirmed by the suggested experimental work.

Our literature review (Sutter 1982) indicated little experimental work has been done to investigate flashing sprays. These releases occur in accidents where liquids pass from a region of high pressure to a low pressure environment. If the liquid vapor pressure exceeds the low pressure, some of the mass shifts into the vapor state to maintain equilibrium. Superheating of the upper zone relative to the lower zone of a system produces flashing. This type of release would relate particularly to fire accident scenarios where heated solutions pressurize and subsequently rupture containers. Thus, hot solutions are jetted into the air producing aerosols of fine particles. Currently, available empirical data are used to estimate drop sizes, requiring multiple models. Volume flow in flashing sprays has been calculated by summing over drop size ranges (Ostrowski 1966). Calculating from another study (Brown 1961) of flashing sprays, Mishima (1976) estimated that $<0.3 \%$ of the amount released would be in a size range that could be transported downwind and become an inhalation hazard.

Because enclosure size limited our experiments, it would be desirable to perform pressurized releases in a larger enclosure, representing additional realistic situations. Using a larger enclosure would allow investigation of the release as a function of distance from the event.

Another matter of interest is the use of other particulate materials such as ion exchange resin in the PARE. Contaminated ion exchange resins have been involved in pressurized release accidents. A radioactively traced resin could be ejected from the chamber and particle size of the release compared to the original size. Work using this type of material indicates that the fraction less than $10 \mu \mathrm{m}$ is insignificant (Ames 1959, Swift 1962). However, resins might be shattered in an event and produce fines. Or the resin could be degraded prior to the event and contain fines that would become airborne. The possibility that resins burn upon release exists, and a fire-generated aerosol is possible. 
Pressurized releases into flowing airstreams are another potential study area. Since additional stresses can be anticipated in this situation, larger releases might be expected.

Thus, there are many options for continuing investigations of pressurized release accident scenarios. This project is not designed to be a study of all parameters, but rather an empirical look at lower and upper boundary airborne releases (with minimum parameter variation) within a nuclear fuel cycle manufacturing facility. Therefore, a few pressurized release accident scenarios could be identified to study for ongoing work. 


\section{REFERENCES}

Ames, L. L. 1959. Zeolite Extraction of Cesium from Aqueous Solutions. HW-62607, Hanford Atomic Products Operation, General Electric Company, Richland, Washington.

Brown, R. and L. J. York. 1961. "Sprays Formed by Flashing Liquid Sprays." AIChE Journal, (8)2.

Castleman, A. W., Jr., F. L. Horn, and G. C. Lindauer. 1969. On the Behavior of Aerosols Under Fast Reactor Accident Conditions. BNL-14070, Brookhaven National Laboratory, Upton, New York.

Committee Report to the Richland Office of the Department of Energy. 1979. Rupture of Plutonium 0xide Storage Container, March 13, 1979.

Mishima, J. 1975. "Data Useful in Evaluation of Airborne Plutonium from Postulated Accident Situations." In Appendix F of Considerations in the Assessment of the Consequences of Effluents from Mixed Oxide Fuel Fabrication Plants, J. M. Selby, et al. BNWL-1697 REV1, p. F-11, Pacific Northwest Laboratory, Richland, Washington.

Mishima, J. 1976. "Potential Aerosol Generation Mechanisms from Damaged Packages." IAEA-SR 10/15, from Transport Packaging for Radioactive Materials, proceedings of a seminar, Vienna.

Ostrowski, H. S. 1966. Evaporation and Induced Air Flow in Sprays Produced by Superheated Water Sprays. Dissertation, University of Michigan.

Seefeldt, W. B., and W. J. Mecham. 1978. "Environmental Effects." Chemical Engineering Division Fuel Cycle Programs Progress Report October - December 1977. ANL-78-77, Argonne National Laboratory, Argonne, Illinois.

Sutter, S. L. 1982. Accident Generated Particulate Materials and Their Characteristics - A Review of Background Information. NUREG/CR-2651. Pacific Northwest Laboratory, Richland, Washington.

Sutter, S. L., J. W. Johnston, and J. Mishima. 1981. Aerosols Generated by Free Fall Spills of Powders and Solutions In Static Air. NUREG/CR-2139, Pacific Northwest Laboratory, Richland, Washington.

Swain E. 0. and H. D. Haberman. 1961. Plutonium Emission Rates from Various Incidents in the 234-5 Building. HW-89064. General Electric Company, Richland, Washington.

Swift, W. H. 1962. Fission Product and Waste Packaging by Inorganic Zeolite Absorption. HW-73964, Hanford Laboratories Operation, General Electric Company, Richland, Washinigton. 
APPENDIX A

MASS AIRBORNE RESULTING FROM PRESSURIZED POWDER AND LIQUID RELEASES IN STATIC AIR 
TABLE A.1. Mass Airborne from Pressurized Releases of DU0 Powder

\begin{tabular}{|c|c|c|c|c|c|c|c|}
\hline $\begin{array}{c}\text { Source } \\
\mathrm{g}\end{array}$ & Rep. (a) & Run (b) & psig & $\begin{array}{c}\text { Weight, } \\
\mathrm{g}\end{array}$ & $\begin{array}{c}\text { Average, } \\
\text { wt g } \\
\end{array}$ & $\begin{array}{c}\text { wt\% } \\
\text { Airborne }\end{array}$ & $\begin{array}{r}\text { Avg wt\% } \\
\text { Airborne } \\
\end{array}$ \\
\hline \multirow[t]{3}{*}{350} & $\begin{array}{l}1 \\
2\end{array}$ & $\begin{array}{r}1 \\
13\end{array}$ & $\begin{array}{l}500 \\
500\end{array}$ & $\begin{array}{l}29.7028 \\
30.7083\end{array}$ & 30.2056 & $\begin{array}{l}9 \\
9\end{array}$ & 9 \\
\hline & $\begin{array}{l}1 \\
2\end{array}$ & $\begin{array}{r}6 \\
14\end{array}$ & $\begin{array}{l}250 \\
250\end{array}$ & $\begin{array}{l}19.1341 \\
21.9318\end{array}$ & 20.5330 & $\begin{array}{l}6 \\
6\end{array}$ & 6 \\
\hline & $\begin{array}{l}1 \\
2\end{array}$ & $\begin{array}{r}4 \\
8 \mathrm{~B}\end{array}$ & $\begin{array}{l}50 \\
50\end{array}$ & $\begin{array}{l}7.0006 \\
6.7570\end{array}$ & 6.8788 & $\begin{array}{l}2 \\
2\end{array}$ & 2 \\
\hline \multirow[t]{3}{*}{100} & $\begin{array}{l}1 \\
2\end{array}$ & $\begin{array}{r}7 \\
12\end{array}$ & $\begin{array}{l}500 \\
500\end{array}$ & $\begin{array}{l}21.2210 \\
18.3406\end{array}$ & 19.7814 & $\begin{array}{l}21 \\
18\end{array}$ & 20 \\
\hline & $\begin{array}{l}1 \\
2\end{array}$ & $\begin{array}{r}3 \\
9 B\end{array}$ & $\begin{array}{l}250 \\
250\end{array}$ & $\begin{array}{l}12.6345 \\
13.3580\end{array}$ & 12.9963 & $\begin{array}{l}13 \\
13\end{array}$ & 13 \\
\hline & $\begin{array}{l}1 \\
2\end{array}$ & 12 & $\begin{array}{l}50 \\
50\end{array}$ & $\begin{array}{l}3.3166 \\
3.7947\end{array}$ & 3.5557 & $\begin{array}{l}3 \\
4\end{array}$ & 4 \\
\hline
\end{tabular}

(a) This is the replicate identification number

(b) Run number, used to identify experiment since they were done in a random sequence. 
TABLE A.2. Mass Airborne from Pressurized Releases of $\mathrm{Ti}_{2}$ Powder

\begin{tabular}{|c|c|c|c|c|c|c|c|}
\hline $\begin{array}{c}\text { Source, } \\
\mathrm{g} \\
\end{array}$ & Rep. & Run & psig & $\begin{array}{c}\text { Weight, } \\
\mathrm{g}\end{array}$ & $\begin{array}{c}\text { Average, } \\
\text { wt g }\end{array}$ & $\begin{array}{c}\text { wt\% } \\
\text { Airborne } \\
\end{array}$ & $\begin{array}{l}\text { Avg wt\% } \\
\text { Airborne }\end{array}$ \\
\hline \multirow[t]{6}{*}{350} & 1 & $5^{(a)}$ & 1000 & 15.8805 & 15.8805 & 4.5 & 4.5 \\
\hline & $\begin{array}{l}1 \\
2\end{array}$ & $\begin{array}{r}4 \\
16\end{array}$ & $\begin{array}{l}500 \\
500\end{array}$ & $\begin{array}{l}21.3782 \\
34.2035\end{array}$ & 27.7909 & $\begin{array}{l}6.1 \\
9.8\end{array}$ & 7.9 \\
\hline & 1 & 3 & 250 & 10.1143 & 102005 & 2.89 & \\
\hline & 1 & 2(a) & 100 & 3.2783 & 3.2783 & 0.94 & 0.94 \\
\hline & 1 & 1 & 50 & 2.1848 & & 0.62 & \\
\hline & 2 & 15 & 50 & 12.5796 & 7.3822 & 3.6 & 2.1 \\
\hline \multirow[t]{5}{*}{100} & 1 & $7^{(a)}$ & 1000 & 12.3933 & 12.3933 & 12.4 & 12.4 \\
\hline & $\begin{array}{l}1 \\
2\end{array}$ & $\begin{array}{l}13 \\
18\end{array}$ & $\begin{array}{l}500 \\
500\end{array}$ & $\begin{array}{l}29.4976 \\
18.7731\end{array}$ & 24.1354 & $\begin{array}{l}29.5 \\
18.8\end{array}$ & 24.1 \\
\hline & $\begin{array}{l}1 \\
2\end{array}$ & $\begin{array}{r}11 \\
9\end{array}$ & $\begin{array}{l}250 \\
250\end{array}$ & $\begin{array}{l}19.8395 \\
16.5683\end{array}$ & 18.2039 & $\begin{array}{l}19.8 \\
16.7\end{array}$ & 18.2 \\
\hline & 1 & $10^{(b)}$ & 189 & 11.0536 & 11.0536 & 11.1 & 11.1 \\
\hline & $\begin{array}{l}1 \\
2\end{array}$ & $\begin{array}{l}6 \\
7\end{array}$ & $\begin{array}{l}50 \\
50\end{array}$ & $\begin{array}{l}3.6082 \\
5.1346\end{array}$ & 4.3714 & $\begin{array}{l}3.6 \\
5.1\end{array}$ & 4.4 \\
\hline 50 & 1 & $8(a)$ & 50 & 0.51 & 0.51 & 1.0 & 1.0 \\
\hline
\end{tabular}

(a) Single value only

(b) Premature rupture 
IABLE A.3. $\mathrm{TiO}_{2}$ Powder Airborne, Powder Release Above Chamber (PRAC)

\begin{tabular}{|c|c|c|c|c|}
\hline $\begin{array}{c}\text { Source, } \\
\mathrm{g} \\
\end{array}$ & Run & psig & $\begin{array}{c}\text { Weight, } \\
\mathrm{g}\end{array}$ & $\begin{array}{c}\text { wt\% } \\
\text { Airborne }\end{array}$ \\
\hline 350 & $\begin{array}{l}1 \\
5\end{array}$ & $\begin{array}{l}500 \\
250\end{array}$ & & $\begin{array}{l}10.9 \\
10.5\end{array}$ \\
\hline & 4 & 50 & 15.86 & 4.5 \\
\hline 100 & $\begin{array}{l}6 \\
3 \\
2\end{array}$ & $\begin{array}{r}500 \\
250 \\
50\end{array}$ & $\begin{array}{r}28.7369 \\
21.3226 \\
8.1773\end{array}$ & $\begin{array}{r}28.7 \\
21.3 \\
8.2\end{array}$ \\
\hline
\end{tabular}


TABLE A.4. Mass Airborne from Pressurized Releases of Uranine Solutions

\begin{tabular}{|c|c|c|c|c|c|c|c|c|}
\hline $\begin{array}{l}\text { Source } \\
\mathrm{cm}^{3}\end{array}$ & Rep. & Run & psig & $\begin{array}{c}\text { Uranine } \\
\text { Collected } \\
\text { on Samples, } \\
g\end{array}$ & $\begin{array}{c}\text { Mass } \\
\text { Airborne, } \\
\mathrm{g} \\
\end{array}$ & $\begin{array}{l}\text { Avg Mass } \\
\text { Airborne, } \\
\mathrm{g} \\
\end{array}$ & $\begin{array}{c}\text { wt\% } \\
\text { Airborne } \\
\end{array}$ & $\begin{array}{l}\text { Avg wt\% } \\
\text { Airborne }\end{array}$ \\
\hline \multirow[t]{3}{*}{350} & $\begin{array}{l}1 \\
2\end{array}$ & $\begin{array}{r}1 \\
13\end{array}$ & $\begin{array}{l}500 \\
500\end{array}$ & $\begin{array}{l}2.0648 \times 10^{-3} \\
1.2855 \times 10^{-3}\end{array}$ & $\begin{array}{l}0.206 \\
0.129\end{array}$ & 0.167 & $\begin{array}{l}0.06 \\
0.04\end{array}$ & 0.05 \\
\hline & $\begin{array}{l}1 \\
2\end{array}$ & $\begin{array}{r}6 \\
14\end{array}$ & $\begin{array}{l}250 \\
250\end{array}$ & $\begin{array}{l}2.2858 \times 10^{-4} \\
4.1983 \times 10^{-4}\end{array}$ & $\begin{array}{l}0.023 \\
0.042\end{array}$ & 0.033 & $\begin{array}{l}0.007 \\
0.012\end{array}$ & 0.010 \\
\hline & $\begin{array}{l}1 \\
2\end{array}$ & $\begin{array}{l}4 \\
8\end{array}$ & $\begin{array}{l}50 \\
50\end{array}$ & $\begin{array}{l}1.2902 \times 10^{-5} \\
4.2090 \times 10^{-5}\end{array}$ & $\begin{array}{l}0.0013 \\
0.0042\end{array}$ & 0.0028 & $\begin{array}{l}0.0004 \\
0.0012\end{array}$ & 0.0008 \\
\hline \multirow[t]{3}{*}{100} & $\begin{array}{l}1 \\
2\end{array}$ & $\begin{array}{r}7 \\
12\end{array}$ & $\begin{array}{l}500 \\
500\end{array}$ & $\begin{array}{l}1.8406 \times 10^{-3} \\
1.1070 \times 10^{-3}\end{array}$ & $\begin{array}{l}0.18 \\
0.11\end{array}$ & 0.15 & $\begin{array}{l}0.18 \\
0.11\end{array}$ & 0.15 \\
\hline & $\begin{array}{l}1 \\
2\end{array}$ & $\begin{array}{l}3 \\
9\end{array}$ & $\begin{array}{l}250 \\
250\end{array}$ & $\begin{array}{l}4.4711 \times 10^{-4} \\
6.5027 \times 10^{-4}\end{array}$ & $\begin{array}{l}0.04 \\
0.07\end{array}$ & 0.06 & $\begin{array}{l}0.04 \\
0.07\end{array}$ & 0.06 \\
\hline & $\begin{array}{l}1 \\
2\end{array}$ & $2^{(a, b)}$ & $\begin{array}{l}50 \\
50\end{array}$ & $\begin{array}{l}4.4217 \times 10^{-6} \\
5.0652 \times 10^{-5}\end{array}$ & $\begin{array}{l}0.004 \\
0.005\end{array}$ & 0.005 & $\begin{array}{l}0.004 \\
0.005\end{array}$ & 0.005 \\
\hline
\end{tabular}

(a) Impactor sample suspect, removed from analysis

(b) $1 \mathrm{~g} / \mathrm{l}$, other runs used $10 \mathrm{~g} / \ell$ solution 
TABLE A.5. Mass Airborne from Pressurized Releases of UNH Solutions

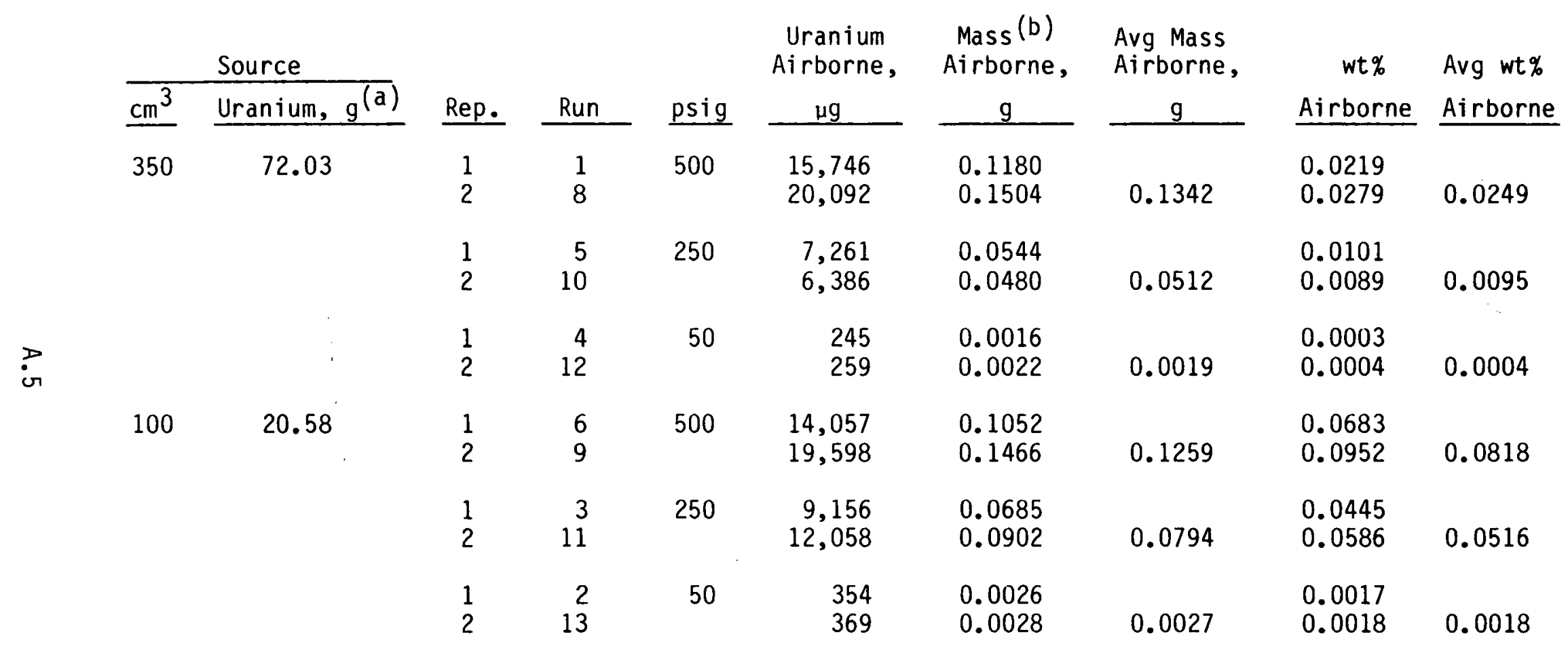

(a) Source $=0.2058 \mathrm{~g} / \mathrm{cm}^{3} ; \mathrm{g} / \mathrm{cm}^{3} \times \mathrm{cm}^{3}=\mathrm{g}$ in source

(b) Calculated using a measured UNH density of $1.54 \mathrm{~g} / \mathrm{cm}^{3}$ 
TABLE A.6. Volume of Liquid Ejected from the PARE

\begin{tabular}{|c|c|c|c|c|}
\hline \multirow[b]{2}{*}{$\begin{array}{c}\text { Pressure, } \\
\text { psig }\end{array}$} & \multicolumn{2}{|c|}{$350 \mathrm{~cm}^{3}$ Source } & \multicolumn{2}{|c|}{$100 \mathrm{~cm}^{3}$ Source } \\
\hline & $\begin{array}{c}\text { Uraninge, } \\
\mathrm{cm}^{2}\end{array}$ & $\begin{array}{l}\text { UN, } \\
\mathrm{cm}^{3}\end{array}$ & $\begin{array}{c}\text { Uraninge, } \\
\mathrm{cm}^{2}\end{array}$ & $\begin{array}{l}\text { UNH, } \\
\mathrm{cm}^{3}\end{array}$ \\
\hline 500 & 17,10 & 10,9 & 3,6 & 9,6 \\
\hline 250 & 7,8 & 8,5 & 2,10 & 5,7 \\
\hline 50 & 5,9 & 4,8 & 2,4 & 3,6 \\
\hline
\end{tabular}




\section{APPENDIX B}

MEDIAN AERODYNAMIC EQUIVALENT DIAMETER (AED) OF PARTICLES GENERATED BY PRESSURIZED POWDER AND LIQUID RELEASES IN STATIC AIR 
TABLE B.1. Median AED of Particles Produced by Pressurized Releases of DU0

\begin{tabular}{|c|c|c|c|c|c|c|c|}
\hline $\begin{array}{c}\text { Source, } \\
\mathrm{g}\end{array}$ & Rep. & Run & psig & $\begin{array}{c}\text { Median } \\
\text { Diameter, } \\
\mu \mathrm{m}\end{array}$ & $\underline{\sigma g}$ & $\begin{array}{l}\text { wt } \% \cdot 10 \mu \mathrm{m} \\
\text { or Less } \\
\end{array}$ & $\begin{array}{c}\text { of Source } \\
\text { that Becomes } \\
\text { Airborne } \\
10 \mu \mathrm{m} \text { and Less } \\
\end{array}$ \\
\hline \multirow[t]{3}{*}{350} & $\begin{array}{l}1 \\
2\end{array}$ & $\begin{array}{r}1 \\
13\end{array}$ & $\begin{array}{l}500 \\
500\end{array}$ & $\begin{array}{l}16 \\
16\end{array}$ & $\begin{array}{l}3.0 \\
3.0\end{array}$ & $\begin{array}{l}34 \\
31\end{array}$ & $\begin{array}{l}3.0 \\
2.7\end{array}$ \\
\hline & $\frac{1}{2}$ & $\begin{array}{r}6 \\
14\end{array}$ & $\begin{array}{l}250 \\
250\end{array}$ & $\begin{array}{l}12 \\
18\end{array}$ & $\begin{array}{l}2.1 \\
3.0\end{array}$ & $\begin{array}{l}42 \\
29\end{array}$ & $\begin{array}{l}2.3 \\
1.8\end{array}$ \\
\hline & $\begin{array}{l}1 \\
2\end{array}$ & $\begin{array}{r}4 \\
8 \mathrm{~B}\end{array}$ & $\begin{array}{l}50 \\
50\end{array}$ & $\begin{array}{l}16 \\
21\end{array}$ & $\begin{array}{l}3.0 \\
4.8\end{array}$ & $\begin{array}{l}33 \\
31\end{array}$ & $\begin{array}{l}0.7 \\
0.6\end{array}$ \\
\hline \multirow[t]{3}{*}{100} & $\begin{array}{l}1 \\
2\end{array}$ & $\begin{array}{r}7 \\
12\end{array}$ & $\begin{array}{l}500 \\
500\end{array}$ & $\begin{array}{l}10 \\
18\end{array}$ & $\begin{array}{l}2.5 \\
4.0\end{array}$ & $\begin{array}{l}49 \\
38\end{array}$ & $\begin{array}{r}10.4 \\
7.0\end{array}$ \\
\hline & $\begin{array}{l}1 \\
2\end{array}$ & $\begin{array}{r}3 \\
9 \mathrm{~B}\end{array}$ & $\begin{array}{l}250 \\
250\end{array}$ & $\begin{array}{r}9 \\
12\end{array}$ & $\begin{array}{l}2.2 \\
1.9\end{array}$ & $\begin{array}{l}54 \\
38\end{array}$ & $\begin{array}{l}6.8 \\
5.1\end{array}$ \\
\hline & $\begin{array}{l}1 \\
2\end{array}$ & $\begin{array}{r}2 \\
11\end{array}$ & $\begin{array}{l}50 \\
50\end{array}$ & $\begin{array}{l}13 \\
25\end{array}$ & $\begin{array}{l}2.9 \\
4.2\end{array}$ & $\begin{array}{l}41 \\
25\end{array}$ & $\begin{array}{l}1.4 \\
1.0\end{array}$ \\
\hline
\end{tabular}


IABLE B.2. Median AED of Particles Produced by Pressurized Releases of $\mathrm{TiO}_{2}$

\begin{tabular}{|c|c|c|c|c|c|c|c|}
\hline $\begin{array}{c}\text { Source, } \\
\mathrm{g} \\
\end{array}$ & Rep. & Run & psig & $\begin{array}{c}\text { Median } \\
\text { Diameter, } \\
\mu \mathrm{m}\end{array}$ & $\sigma g$ & $\begin{array}{l}\% 10 \mu \mathrm{m} \\
\text { or Less }\end{array}$ & $\begin{array}{c}\text { wt\% } \\
\text { of Source } \\
\text { that Becomes } \\
\text { Airborne } \\
10 \mu \mathrm{m} \text { and Less } \\
\end{array}$ \\
\hline \multirow[t]{5}{*}{350} & 1 & ${ }_{5}(a)$ & 1000 & 7.0 & 4.1 & 64 & 2.9 \\
\hline & $\begin{array}{l}1 \\
2\end{array}$ & $\begin{array}{l}4^{(b)} \\
16\end{array}$ & $\begin{array}{l}500 \\
500\end{array}$ & 15,12 & $10.7,8.6$ & 40,44 & $3.9,4.3$ \\
\hline & $\begin{array}{l}1 \\
2\end{array}$ & $\frac{3}{14}(\mathrm{~b})$ & $\begin{array}{l}250 \\
250\end{array}$ & 14 & 8.5 & 44 & 3.3 \\
\hline & 1 & $2^{(b)}$ & 100 & & & & \\
\hline & $\begin{array}{l}1 \\
2\end{array}$ & $\begin{array}{r}1(b) \\
15(c)\end{array}$ & $\begin{array}{l}50 \\
50\end{array}$ & 20,16 & $13,10.3$ & 38,48 & $1.4,1.7$ \\
\hline \multirow[t]{5}{*}{100} & 1 & $7^{(a)}$ & 1000 & 5.6 & 8.2 & 60 & 7.4 \\
\hline & $\frac{1}{2}$ & $\begin{array}{l}13 \\
18\end{array}$ & $\begin{array}{l}500 \\
500\end{array}$ & $\begin{array}{ll}4.6, & 4.2 \\
6.9, & 5.0\end{array}$ & $\begin{array}{ll}6.3, & 5.5 \\
6.0,6\end{array}$ & $\begin{array}{l}68,72 \\
54,66\end{array}$ & $\begin{array}{ll}20.1, & 21.2 \\
10.1, & 12.4\end{array}$ \\
\hline & $\begin{array}{l}1 \\
2\end{array}$ & $\begin{array}{r}11 \\
9\end{array}$ & $\begin{array}{l}250 \\
250\end{array}$ & $\begin{array}{ll}10, & 8.3 \\
17, & 6.4\end{array}$ & $\begin{array}{l}9.5,5.7 \\
14,5.8\end{array}$ & $\begin{array}{ll}50, & 54 \\
42, & 61\end{array}$ & $\begin{array}{ll}9.9, & 10.7 \\
6.9, & 10.1\end{array}$ \\
\hline & 1 & $10(d)$ & 189 & 14,10 & $10.8,4.5$ & 44,50 & $4.9,5.5$ \\
\hline & $\begin{array}{l}1 \\
2\end{array}$ & $\begin{array}{r}6 \\
17\end{array}$ & $\begin{array}{l}50 \\
50\end{array}$ & $\begin{array}{l}8.2 \\
9.2,6.8\end{array}$ & $\begin{array}{l}5.9 \\
5.1,4.3\end{array}$ & $\begin{array}{l}54 \\
52,60\end{array}$ & $\begin{array}{l}1.9 \\
2.7,3.1\end{array}$ \\
\hline 50 & 1 & $8^{(e)}$ & 50 & 12 & 8.6 & 48 & 0.5 \\
\hline
\end{tabular}

(a) Exploratory at 1000 psig

(b) Impactor overloaded

(c) Data based on 2 impactors where two sizes are shown

(d) Run originally set for $250 \mathrm{psig}$, went off prematurely

(e) Exploratory at $50 \mathrm{psig}$ and using $50 \mathrm{~g}$ traced $\mathrm{TiO}_{2}$ 
TABLE B.3. Median AED of Particles Produced by $\mathrm{TiO}_{2}$ Powder Releases Above Chamber (PRAC)

\begin{tabular}{|c|c|c|c|c|c|c|}
\hline $\begin{array}{c}\text { Source, } \\
\mathrm{g}\end{array}$ & Run & psig & $\begin{array}{c}\text { Median } \\
\text { Diameter, } \\
\mu \mathrm{m}\end{array}$ & $\sigma g$ & $\begin{array}{r}\% 10 \mu \mathrm{m} \\
\text { and Less } \\
\end{array}$ & $\begin{array}{c}\text { Avg wt\% } \\
\text { of Source } \\
\text { that Becomes } \\
\text { Airborne and is } \\
10 \mu \mathrm{m} \text { and Less } \\
\end{array}$ \\
\hline \multirow[t]{4}{*}{350} & 1 & 500 & $\begin{array}{c}20^{(a)} \\
9\end{array}$ & 11.8 & $\begin{array}{l}54 \\
40\end{array}$ & 5.1 \\
\hline & 5 & 250 & $\begin{array}{r}11 \\
5\end{array}$ & $\begin{array}{l}5.5 \\
3.6\end{array}$ & $\begin{array}{l}48 \\
72\end{array}$ & 6.3 \\
\hline & 4 & 50 & 12 & 9.2 & 46 & \\
\hline & & & 2.4 & 3.8 & 88 & 3.0 \\
\hline \multirow[t]{3}{*}{100} & 6 & 500 & $\begin{array}{l}11 \\
4.3\end{array}$ & $\begin{array}{l}7.7 \\
4.0\end{array}$ & $\begin{array}{l}48 \\
71\end{array}$ & 17.1 \\
\hline & 3 & 250 & $\begin{array}{r}10.1 \\
6.2\end{array}$ & $\begin{array}{l}5.3 \\
4.4\end{array}$ & $\begin{array}{l}48 \\
65\end{array}$ & 12.0 \\
\hline & 2 & 50 & $\begin{array}{l}8.4 \\
6\end{array}$ & $\begin{array}{l}6.5 \\
7.0\end{array}$ & $\begin{array}{l}53 \\
68\end{array}$ & 5.0 \\
\hline
\end{tabular}

(a) Based on two impactor samples 
TABLE B.4. Median AED of Particles Produced by Pressurized Releases of Uranine Solutions

\begin{tabular}{|c|c|c|c|c|c|c|c|}
\hline $\begin{array}{c}\text { Sounce, } \\
\mathrm{cm}^{3}\end{array}$ & Rep. & Run & psig & $\begin{array}{c}\text { Median } \\
\text { Diameter, } \\
\mu \mathrm{m}\end{array}$ & $\sigma_{g}$ & $\begin{array}{l}\% 10 \mu \mathrm{m} \\
\text { and Less }\end{array}$ & $\begin{array}{c}\text { wt } \% \\
\text { of Source } \\
\text { that becomes } \\
\text { Airborne } \\
10 \mu m \text { and Less }\end{array}$ \\
\hline 350 & $\begin{array}{l}1 \\
2\end{array}$ & $\begin{array}{r}1 \\
13\end{array}$ & $\begin{array}{l}500 \\
500\end{array}$ & $\begin{array}{l}4 \\
4.3\end{array}$ & $\begin{array}{l}3 \\
2.4\end{array}$ & $\begin{array}{r}86 \\
85\end{array}$ & $\begin{array}{l}0.05 \\
0.03\end{array}$ \\
\hline \multirow{5}{*}{100} & $\begin{array}{l}1 \\
2\end{array}$ & $\begin{array}{r}6 \\
14\end{array}$ & $\begin{array}{l}250 \\
250\end{array}$ & $\begin{array}{l}4 \\
3.6\end{array}$ & $\begin{array}{l}1.6 \\
3\end{array}$ & $\begin{array}{l}98 \\
84\end{array}$ & $\begin{array}{l}0.007 \\
0.01\end{array}$ \\
\hline & $\begin{array}{l}1 \\
2\end{array}$ & $\begin{array}{l}4 \\
8\end{array}$ & $\begin{array}{l}50 \\
50\end{array}$ & $\begin{array}{l}1.5 \\
2.1\end{array}$ & $\begin{array}{l}3 \\
4\end{array}$ & $\begin{array}{l}83 \\
87\end{array}$ & $\begin{array}{l}0.0003 \\
0.001\end{array}$ \\
\hline & $\begin{array}{l}1 \\
2\end{array}$ & $\begin{array}{r}7 \\
12\end{array}$ & $\begin{array}{l}500 \\
500\end{array}$ & $\begin{array}{l}4 \\
4.0\end{array}$ & $\begin{array}{l}3 \\
4\end{array}$ & $\begin{array}{l}90 \\
70\end{array}$ & $\begin{array}{l}0.16 \\
0.08\end{array}$ \\
\hline & $\begin{array}{l}1 \\
2\end{array}$ & $\begin{array}{l}3 \\
9\end{array}$ & $\begin{array}{l}250 \\
250\end{array}$ & $\begin{array}{l}2.4 \\
4\end{array}$ & $\begin{array}{l}4 \\
3.6\end{array}$ & $\begin{array}{l}78 \\
77\end{array}$ & $\begin{array}{l}0.03 \\
0.05\end{array}$ \\
\hline & 2 & 11 & 50 & 2.1 & 4 & 80 & 0.004 \\
\hline
\end{tabular}


TABLE B.5. Median AED of Particles Produced by Pressurized Releases of UNH

\begin{tabular}{|c|c|c|c|c|c|c|c|}
\hline $\begin{array}{c}\text { Source, } \\
\mathrm{cm}^{3}\end{array}$ & Rep. & Run & psig & $\begin{array}{c}\text { Median } \\
\text { Diameter, } \\
\mu \mathrm{m}\end{array}$ & $\sigma \mathrm{g}$ & $\begin{array}{l}\% 10 \mu \mathrm{m} \\
\text { and Less }\end{array}$ & $\begin{array}{l}\text { wt\% } \\
\text { of source } \\
\text { that Becomes } \\
\text { Airborne } \\
10 \mu m \text { and Less }\end{array}$ \\
\hline 350 & $\begin{array}{l}1 \\
2\end{array}$ & $\begin{array}{l}1 \\
8\end{array}$ & 500 & $\begin{array}{l}17 \\
14\end{array}$ & $\begin{array}{l}4.0 \\
2.9\end{array}$ & $\begin{array}{l}34 \\
37\end{array}$ & $\begin{array}{l}0.0074 \\
0.0103\end{array}$ \\
\hline & $\begin{array}{l}1 \\
2\end{array}$ & $\begin{array}{r}5 \\
10\end{array}$ & 250 & $\begin{array}{l}45 \\
12\end{array}$ & $\begin{array}{l}5.9 \\
2.9\end{array}$ & $\begin{array}{l}20 \\
45\end{array}$ & $\begin{array}{l}0.0018 \\
0.0040\end{array}$ \\
\hline & $\begin{array}{l}1 \\
2\end{array}$ & $\begin{array}{r}4 \\
12\end{array}$ & 50 & $\begin{array}{l}3 \\
5\end{array}$ & $\begin{array}{l}4.8 \\
5.2\end{array}$ & $\begin{array}{l}76 \\
70\end{array}$ & $\begin{array}{l}0.0002 \\
0.0003\end{array}$ \\
\hline 100 & $\begin{array}{l}1 \\
2\end{array}$ & $\begin{array}{l}6 \\
9\end{array}$ & 500 & $\begin{array}{l}14 \\
14\end{array}$ & $\begin{array}{l}2.5 \\
2.9\end{array}$ & $\begin{array}{l}46 \\
38\end{array}$ & $\begin{array}{l}0.0314 \\
0.0362\end{array}$ \\
\hline & $\begin{array}{l}1 \\
2\end{array}$ & $\begin{array}{r}3 \\
11\end{array}$ & 250 & $\begin{array}{l}14 \\
11\end{array}$ & $\begin{array}{l}2.7 \\
4.6\end{array}$ & $\begin{array}{l}36 \\
45\end{array}$ & $\begin{array}{l}0.0160 \\
0.0264\end{array}$ \\
\hline & $\begin{array}{l}1 \\
2\end{array}$ & $\begin{array}{r}2 \\
13\end{array}$ & 50 & $\begin{array}{l}6 \\
8\end{array}$ & $\begin{array}{l}7.5 \\
4.6\end{array}$ & $\begin{array}{l}61 \\
60\end{array}$ & $\begin{array}{l}0.0010 \\
0.0011\end{array}$ \\
\hline
\end{tabular}


DISTRIBUTION

No. of

Copies

OFFSITE

U.S. NRC

Office of Nuclear Reactor Regulation

Division of Systems Integration

Accident Evaluation Branch

Mail Stop P-802

Washington, DC 20555

Attn: W. F. Pasedag

NRC Division of Technical

Information and Document

Control

Tom Fry

Associated Nuclear Services

$123 \mathrm{High}$ Street

Epsom, Surrey

KT19 8EB

UNITED KINGDOM

H. A. Morewitz

Rockwell International

Atomics International Division

P.0. Box 309

Canoga Park, CA 91304

C. W. Griffin

Rockwell International Division

Energy Systems Group

8900 DeSoto Avenue

Canoga Park, CA 91304

F. Yost

Utility Data Institute

2011 I Street, NW

Suite 700

Washington, DC 20006
No. of

Copies

\section{S. S. Grossel}

Corporate Engineering

Department

Hoffman-LaRoche Inc.

Nutley, NJ 07110

F. Rahn

EPRI

P.0. Box 10412

Palo Alto, CA 94303

ONSITE

2 Hanford Engineering Development Laboratory

J. D. McCormack

A. Postma

40 Pacific Northwest Laboratory

M. Y. Ballinger

M. K. Chan

D. W. Dragnich

C. E. Elderkin

J. J. Fuquay

R. K. Hadlock

M. A. Halverson

N. S. Laulainen

J. Mishima

P. C. Owczarski

S. L. Sutter (22)

R. K. Woodruff

Publishing Coordination (2)

Technical Information (5) 


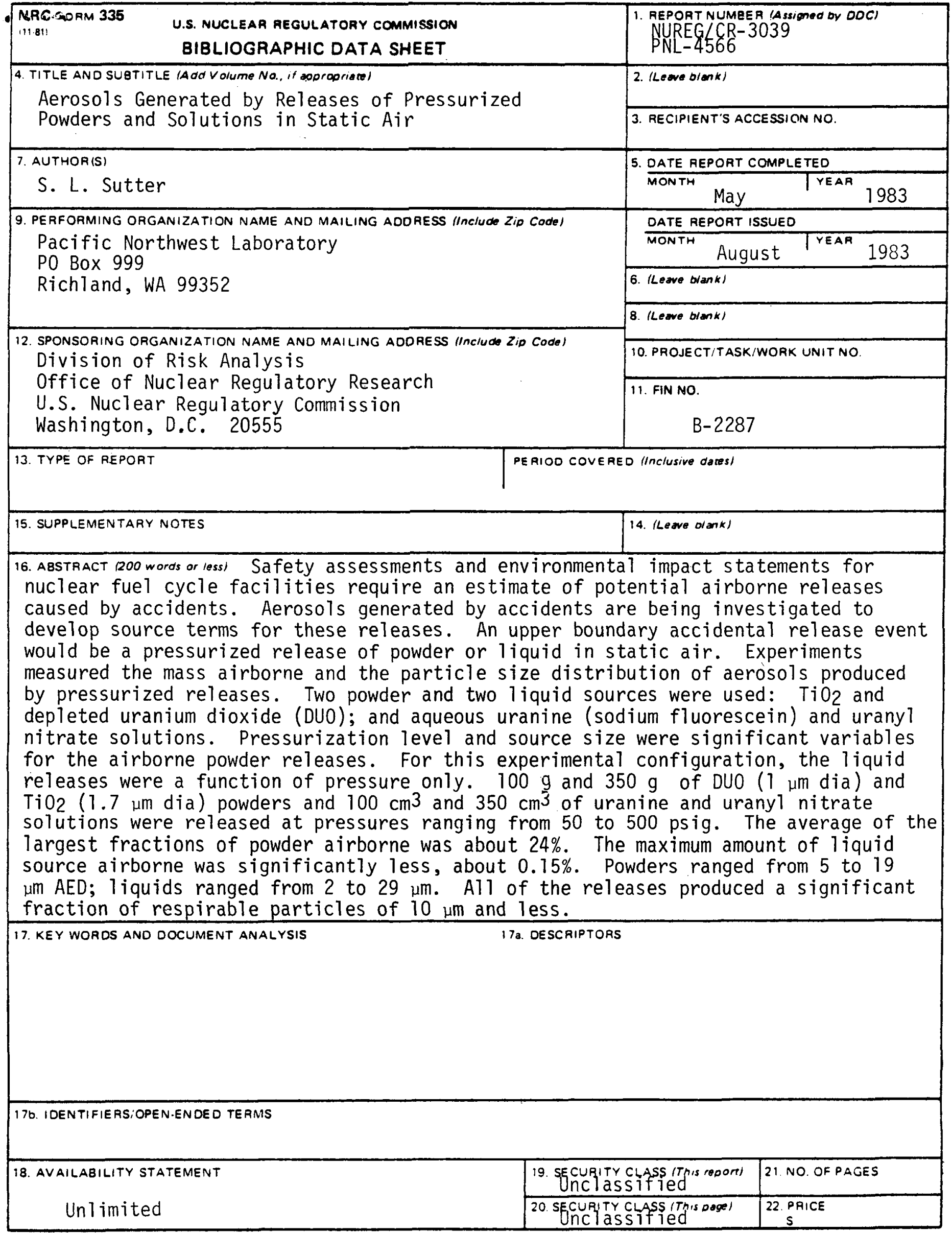


UNITED STATES

NUCLEAR REGULATORY COMMISSION

WASHINGTON, D.C. 20555

OFFICIAL BUSINESS

PENALTY FOR PRIVATE USE, $\$ 300$

\section{“it}

FOURTH.CLASS MAIL POSTAGE \& FIEESPATOFO - USNAC

WAS

PERMIT NO. G.6

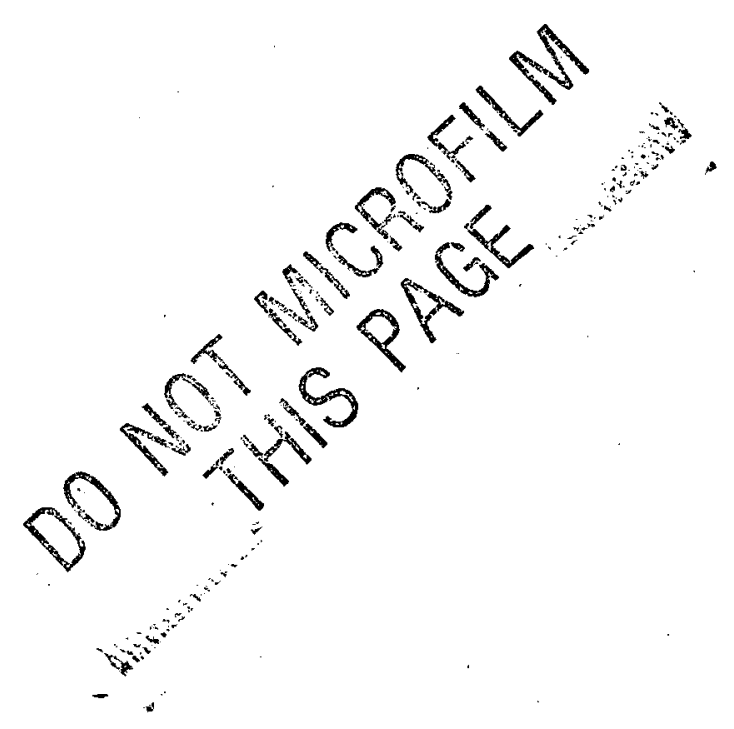

